\title{
POLÍTICAS DE ASIMILACIÓN Y DE PRESERVACIÓN DE LA NACIONALIDAD DE LOS EMIGRANTES. ESPAÑOLES EN FRANCIA, 1900-1936
}

por

\section{ANTONIO NIÑO RODRÍGUEZ}

Universidad Complutense de Madrid

RESUMEN: Este estudio utiliza el caso de la temprana emigración en Francia para analizar la política de asimilación desarrollada por ese país, así como la respuesta del Estado español destinada a preservar la nacionalidad de sus expatriados. En primer lugar se examinan las características profesionales, sociales y culturales de esa emigración, así como su red asociativa en las primeras décadas del siglo XX. Se analizan después las medidas administrativas adoptadas por. las respectivas administraciones, en su silenciosa batalla por controlar a esa población y atraer la voluntad de los emigrantes, y las respuestas de éstos en función de sus propios intereses. Especial atención se dedica a la naturalización legal y a la integración cultural por la vía escolar. Por último, se estudia la progresiva sustitución en Francia de la estrategia asimiladora por otra basada en la exclusión, según se agudiza la crisis económica y social de los años treinta.

PALABRAS Clave: Emigración. Nacionalidad. Identidades colectivas. Asimilación. Políticas migratorias. Relaciones hispano-francesas.

ABSTRACT: This study uses the case of early emigration to France in order to analyse that country's assimilation policies and the efforts of the Spanish state to preserve the national identity of expatriates. Firstly, the professional, social and cultural characteristics of the emigrants are examined, along with the network of associations that was formed in the first decades of the twentieth century. Then the administrative measures adopted by the respective regimes are analysed, in their silent battle to control the emigrant population and attract the goodwill of emigrants, together with the latter's responses arising from their own self-interests. Special attention is dedicated to legal naturalization and cultural integration through the path of education. The final subject to be addressed is the progressive substitution in France of a 


\begin{abstract}
strategy based on assimilation by one based on exclusion, as the economic and social crisis of the 1930s deepened.
\end{abstract}

KEY WORDS: Emigration. National identity. Collective identities. Assimilation. Migration policies. Relations between Spain and France.

«Llevo 16 años en Francia, mas no me pueden dar trabajo à no ser que me naturalice francés, pues heso hes (sic) una cosa que yo jamás lo haré puesto que de hesta (sic) forma renegaría definitivamente à mi patria. Situación de familia casado padre de familia profesión albañil y chaufe (sic), natural de Colmenar de Oreja (Madrid)»1.

La emigración económica hacia Francia, que adquirió un carácter masivo desde las primeras décadas del siglo XX, fue la que abrió el camino de la corriente migratoria al continente europeo, anunciando así un viraje respecto a la tradicional orientación latinoamericana que se acentuaría sobre todo a partir de los años cincuenta del siglo XX. El interés de su estudio radica en que esta corriente inauguró estrategias asociativas, iniciativas de autoprotección y políticas estatales adaptadas al nuevo contexto, que serán luego desarrolladas en las sucesivas oleadas emigratorias de los años sesenta y setenta. Las políticas diseñadas hasta entonces por la administración española, pensadas para la emigración ultramarina, tuvieron que adaptarse a las peculiaridades del contexto europeo. El Estado español hubo de afrontar entonces nuevos problemas asociados a las condiciones laborales, a las necesidades culturales y a la preservación de la nacionalidad de esos emigrantes, que diferían en aspectos sustanciales a los que enfrentaba la emigración hacia Latinoamérica. En este estudio analizaremos las fases y procedimientos que siguió esa adaptación, y la pondremos en relación con las políticas que, paralelamente, aplicaba el Estado francés para controlar e integrar a la nueva inmigración de origen español. Del lado francés se contaba para ello con precedentes y con modelos ya ensayados en la política seguida hacia los contingentes aún más antiguos de la inmigración de origen italiano, belga y polaco.

Hasta hace poco los estudios sobre las oleadas migratorias habían privilegiado los aspectos socio-económicos del fenómeno: se hacían cálculos cuantita-

* Las abreviaturas utilizadas son: AGA: Archivo General de la Administración, Alcalá de Henares. AMAE: Archivo del Ministerio de Asuntos Exteriores, Madrid. AD: Archives Diplomatiques, París.

1 Firma Ignacio Haro desde Mousset (Gironde), 7 de mayo de 1936. AGA, Ministerio de Trabajo, $75 / 23078$, carp. 1 exp. 3

Hispania, LXII/2, núm. 211 (2002) 433-482 
tivos del flujo en origen y destino, se analizaban los factores de expulsión, las motivaciones de los emigrantes, las causas que ayudaron a tomar esa decisión, las estrategias y los mecanismos utilizados, -cadenas migratorias, redes sociales-, el impacto en la sociedad de acogida etc. Mucho se ha debatido sobre sus efectos económicos y laborales, tanto en el momento de la emigración como en el del retorno. Pero todavía sabemos poco sobre sus implicaciones socioculturales y políticas. Ultimamente se tiende a privilegiar el análisis cualitativo y el nivel microsocial, con el fin de profundizar en la comprensión de las consecuencias sociales y culturales de los procesos migratorios. También se ha despertado el interés por abordar dimensiones nuevas del fenómeno como son el asociacionismo, la militancia política del emigrante o el proceso de identificación nacional de los expatriados ${ }^{2}$. A pesar de ello, se sigue olvidando con demasiada frecuencia una de las variables imprescindibles para la comprensión del fenómeno: el papel de los Estados y de su entramado institucional, con su enorme capacidad para condicionar las acciones de los individuos y para ejercer un control más o menos eficaz sobre sus actividades. Se ha dicho que el Estado no supone un factor determinante en los flujos migratorios porque no es capaz por sí mismo de impulsarlos ni de detenerlos, o porque su actuación siempre es una respuesta a situaciones de hecho. Sin embargo, las políticas estatales diseñadas para intervenir sobre los procesos migratorios, arbitradas tanto por los Estados de origen como por los receptores, tienen un enorme interés, a nuestro entender, porque inciden gravemente en las condiciones de vida del emigrante. Basta recordar tres aspectos en los que la intervención estatal resulta fundamental: los derechos laborales y sociales del emigrante, su integración en la sociedad de acogida y su identidad cultural y nacional. Tres aspectos que, como es evidente, concentran hoy día el debate político y social en los países europeos que, como España, reciben crecientes flujos de inmigrantes. Se trata, como veremos, de un debate muy antiguo que intentaremos analizar tal y como se produjo en el primer tercio del siglo XX y a propósito de la emigración española en Francia. En estas cuestiones es importante comprender no sólo la lógica de las políticas estatales, sino también la perspectiva de los propios sujetos de la emigración, los individuos afectados que adaptaban su propia estrategia al marco establecido por las leyes y las políticas estatales, y que exponían sus reclamaciones a través de sus portavoces y sus organizaciones. Tres son, por lo tanto, los actores que vamos a conșiderar: los emigrantes; el Estado español y el Estado francés con sus respectivas administraciones. Tres actores, con distintos intereses, implicados en un complejo juego en el que se mezclaban las reivindicaciones laborales, el reconocimiento de derechos sociales, los procesos de asimilación y rechazo, las percepciones del otro, la defensa de la identidad nacional y los objetivos diplomáticos de los dos Estados.

2 Dada la ingente bibliografía que existe sobre el tema de las migraciones peninsulares, remitimos a los estados de la cuestión elaborados por Juan B. VILAR, Consuelo NARANJO y Antonio SANTAMARÍA en Migraciones y Exilios. Cuadernos de AEMIC, 1 (diciembre 2000), pp. 131-160 y 161-198. 
En el centro de nuestra problemática se halla la cuestión de la identidad nacional de los emigrantes y sus descendientes, sometidos por un lado a las presiones del Estado francés para forzar su integración y, mejor aún, su asimilación en la sociedad de acogida, y objetivo por el otro de los esfuerzos del Estado español por preservar su nacionalidad mediante políticas paternalistas de asistencia benéfica, protección legal y apoyo cultural. Es característico de la época que el problema de la emigración se contemple desde el país emisor no como una fuente de recursos económicos en forma de remesas de divisas - como sucedería durante el régimen de Franco- sino como una sangría nacional que había que contrarrestar con políticas de preservación de los vínculos nacionales. De modo simétrico, es característico de la política francesa hacia la inmigración el poco respeto por sus señas de identidad propias y el esfuerzo por acelerar su asimilación. En el medio de este campo de fuerzas se sitúan los núcleos de emigrados, de muy diferentes características según su inserción regional y profesional, organizados en una variopinta red de sociedades de socorros mutuos, sociedades benéficas, instituciones culturales, clubs deportivos, asociaciones religiosas, obreras, etc. Este movimiento asociativo, expresión de los intereses del colectivo de emigrantes, pero manifestación también de sus fracturas y divisiones, estuvo en el punto de mira de los responsables políticos, ya fuera para vigilarlo en el caso de la administración francesa, o para controlarlo y manipularlo en el caso de las autoridades gubernamentales y consulares españolas. Situados en medio de la confrontación de políticas estatales, los colectivos de emigrantes adoptaron estrategias diversas, según las circunstancias, que iban desde la defensa orgullosa de su nacionalidad, apoyados en sus asociaciones y en la protección de sus autoridades consulares, hasta la asimilación plena en la población local y la adquisición de una nueva ciudadanía. Unas veces el objetivo era escapar del control administrativo al que eran sometidos como expatriados o como extranjeros, utilizando para ello la clandestinidad y diversas formas de mimetismo social. Otras veces el propósito era acceder a los beneficios que les confería la ciudadanía en uno u otro país, para lo que arbitraron diversas fórmulas reivindicativas. El caso de los emigrantes ofrece por lo tanto un mirador excepcional desde el que estudiar la formación, la transformación y la utilización de las identidades colectivas, en especial las identidades nacionales, esos artefactos culturales de tanta trascendencia en la vida social y en la organización política moderna.

La utilización preferente en este estudio de fuentes provenientes de la administración estatal, tanto de la francesa como de la española, plantea el peligro de privilegiar una visión «desde arriba» del fenómeno, que nos muestre su faceta institucional más que las vivencias a él asociadas. Somos conscientes de que las fuentes nos imponen evidentes limitaciones si queremos estudiar la forma en que los propios emigrantes percibían su situación, sus fidelidades nacionales, sus actitudes ante los dos Estados o sus resistencias a la asimilación. Sería pues conveniente completar esta investigación con el uso de documentos personales de los destinatarios de las leyes, de las medidas administrativas y en general de la política seguida respecto a la emigración. La historia sociocultural

Hispania, LXII/2, núm. 211 (2002) 433-482 
y política de la emigración, que es básicamente una realidad microsocial, con sus factores psicológicos y sus estrategias personales, debe completarse con el material empírico de los documentos personales. Las políticas de preservación de la identidad nacional alcanzan su efectividad cuando tienen un efecto «micro", y deben ser evaluadas, naturalmente, por la influencia real que tuvieron en el contexto individual y familiar. Por eso son tan importantes las experiencias vividas por aquellos hombres que abandonaron los espacios sociales que conocían para integrarse en otros contextos nacionales y culturales, y para acceder a esas experiencias, a su percepción de la realidad, apenas contamos con su correspondencia y su memoria.

\section{CARACTERÍSTICAS DE LA EMIGRACIÓN A FRANCIA}

Cualquier intento de abordar un estudio cuantitativo y estadístico de la emigración que se dirigió a principios de siglo hacia Francia ofrecerá resultados inciertos, y ello por diversos motivos. En primer lugar, por la falta de instrumentos de control administrativo, ya que las autoridades españolas sólo realizaban el control estadístico de aquellos que emigraban por mar, a través de las oficinas instaladas en los puertos de embarque autorizados para realizar ese tráfico. Por lo tanto, no existen estadísticas de la emigración que salía por vía terrestre. Si la emigración era por sí misma una realidad difícil de controlar, en el caso de la que se dirigía a Francia el control administrativo ni siquiera se intentó. En segundo lugar, la facilidad para atravesar la frontera pirenaica hacía que las salidas clandestinas, siempre presentes en cualquier flujo, adquirieran en este caso una importancia todavía mayor. Una vez en el país de destino, pocos eran los que se inscribían en el registro de nacionalidad de los consulados - no llegaba al 20\% según el consulado general de París-. Aunque esta formalidad era en principio gratuita, la expedición del certificado correspondiente sí estaba sometida al cobro de tasas, a lo que se sumaba el hecho de que las autoridades francesas no exigían ese requisito para expedir sus cartas de residencia. Nadie creía en la época, y menos sus propios responsables, que los registros consulares ofrecieran una información fidedigna sobre la cantidad de emigrantes instalados en cada circunscripción consular. Por lo tanto, por parte de la administración española no existen datos fiables, y sólo contamos con estimaciones muy vagas que hacían los cónsules sobre la población instalada en sus distritos. De parte francesa la situación es algo mejor: aunque no totalmente fiables, contamos con los censos de población de la Francia metropolitana, que recogen un crecimiento continuo del número de españoles ${ }^{3}$ :

3 Vid. Institut National de la Statistique et des Etudes Economiques, Annuaire statistique de la France, 1966. Résumé rétrospectif, pp. 61-62. Estas cifras son las mismas que utilizan los estudios clásicos 


\begin{tabular}{|c|c|}
\hline AÑo & ESPAÑOLES CENSADOS \\
\hline 1901 & 80.425 \\
1911 & 105.760 \\
1921 & 254.980 \\
1926 & 322.590 \\
1931 & 351.864 \\
1936 & 253.599 \\
\hline
\end{tabular}

En estas cifras no está contemplada la emigración a Argelia, que ofrece características peculiares y que requeriría un análisis diferenciado. Pero estas cantidades son a menudo diferentes de las que proporcionan otras fuentes de la misma administración francesa. Según el Ministerio del Interior francés, por ejemplo, en enero de 1926 había 467.156 españoles de un total de 2.845 .214 extranjeros en Francia —o sea, el 16,4\% de la población extranjera, prácticamente equiparados a los belgas y sólo superados por los 807.659 italianos ${ }^{4}$-, una cifra sensiblemente superior a la que figura en los censos de población.

Este contingente de inmigrantes españoles en Francia osciló a partir de la Primera Guerra Mundial, según el censo, entre el 13 y el $16 \%$ de la población extranjera, sólo superado por el de belgas e italianos, y a partir de los años treinta por el de polacos e italianos. El gran salto se produjo durante el conflicto mundial, y ello por dos motivos: en primer lugar, la declaración de guerra hizo que parte de la emigración que se dirigía tradicionalmente a Latinoamérica se desviara a Francia por la elevación de los precios de los pasajes, por los peligros de la navegación a causa de la guerra submarina, y también por las dificultades económicas que atravesaron esos países provocadas por la propia contienda. En segundo lugar, la escasez de mano de obra en la agricultura y la industria francesa como consecuencia de la movilización bélica hizo que se recurriera de forma masiva al empleo de trabajadores españoles, que procedían de un país neutral y limítrofe, y que podían ser fácilmente reclutados en la frontera por organismos oficiales creados a tal efecto. Estamos pues ante un caso en el que los factores que crean un efecto de atracción son tan importantes al menos como los factores de expulsión. La crisis de mano de obra que se produjo en todos los sectores productivos de la economía francesa actuó como un potente imán, y este efecto se vio a su vez favorecido por una tradición migratoria antigua, por la existencia previa de una colonia ya arraigada —en parte originada por la crónica presencia de desterrados republicanos y carlistas durante el último

sobre el tema: Guy HeRmet, Les Espagnols en France, 1967 y Javier RuBIO, La emigración española en Francia, 1974.

4 Respuesta del Ministerio del Interior a la pregunta de un diputado, cirada en el despacho del embajador en París de 15 de abril de 1926, AGA, 75/23082.

Hispania, LXII/2, núm. 211 (2002) 433-482 
cuarto del siglo XIX X $^{5}$ y por la experiencia regular de la emigración de temporada. La emigración golondrina se venía practicando desde el siglo anterior. La componían cuadrillas de obreros, provenientes de las regiones limítrofes, que iban en las épocas de la siega y la vendimia al Mediodía francés - como lo hacían desde los puertos del Levante y Almería a Argelia-, y regresaban a España una vez terminados esos trabajos agrícolas. Las redes sociales creadas durante largos años de contactos previos potenciaron sin duda el efecto de atracción que generó el mercado laboral francés. durante la Guerra Europea y que se prolongó en los años inmediatamente posteriores. Sólo para los años 1916 a 1918 se calculó un saldo migratorio de 142.629 personas, deducidos los retornos, a los que se añadieron otras 100.000 entre 1919 y $1920^{6}$. A este contingente se fue superponiendo en años sucesivos un flujo continuo de nuevos emigrantes, atraídos por las necesidades laborales de la reconstrucción económica del país. $\mathrm{Si}$ a eso añadimos que esos emigrantes, varones adultos en su inmensa mayoría, solían llamar a sus familias en cuanto adquirían un cierto bienestar, tendremos una explicación al aumento total de españoles que aparecen en los sucesivos censos franceses hasta el de 1931.

Aún así, se puede asegurar que el aumento de estas cifras no refleja adecuadamente la intensidad de la emigración ni la importancia de la aportación española debido al continuo proceso de asimilación de los emigrantes por el procedimiento de la naturalización, que los hacía invisibles en los censos de población. Del mismo modo, el descenso de la primera mitad de los años treinta puede deberse tanto a un aumento de las naturalizaciones - a mediados de los años treinta se estiman en alrededor de 200.000 los franceses de origen español de primera o segunda generación ${ }^{7}$ - como a una interrupción del flujo de la emigración por la crisis económica o a un incremento de los retornos, aunque probablemente la reducción de efectivos se deba a una combinación de los tres factores.

La emigración se concentraba tradicionalmente en el Mediodía francés, especialmente en los departamentos fronterizos, con un progresivo desplazamiento del centro de gravedad de la Gascuña al Languedoc, una región básicamente rural, de débil densidad demográfica y en proceso de despoblamiento después de la guerra europea. A estas zonas de emigración antigua y abundante de braceros españoles se añadieron, a partir de los años veinte, núcleos más pequeños de emigrantes en los departamentos industriales del valle del Ródano y del norte de Francia, y algunos enclaves aislados como las concentraciones mineras de SaintEtienne o las fábricas Michelin y Bergougnan de Clermont-Ferrand ${ }^{8}$.

5 Vid. Eduardo GONZALEZ CALlEJA, «La frontera como protagonista histórico. Observaciones sobre la emigración y la resistencia políticas en la primera etapa de la Restauración (1875-1900)», Exils et Migrations Ibériques au XX $X^{t}$ siècle, 3/4 (1997), pp. 14-36.

6 Vid. M. HuBER, La population de France pendant la guerre, París, PUF, 1931, p. 201.

7 Vid. Yves DENÉCHÈre, «Un enfoque original de la inmigración en tiempos de crisis: un proyecto de simbiosis franco-español en los años treinta», Studia Histórica, 77 (1999), p. 233.

8 En un informe de la inspección de trabajo de 1925 se decía: «Es notorio, sin temor a recurrir a hipérbole, que desde Burdeos a Cette, todo el Sur y el Mediodía de Francia está hoy invadido por obre- 
Una gran proporción de estos trabajadores -en torno al 30\%, el porcentaje más alto entre los inmigrantes extranjeros- se empleaba como asalariados en el sector agrícola. El resto se repartían entre la construcción, las industrias metalúrgicas y mecánicas, y la minería, pero siempre desempeñando las tareas que requerían menor cualificación. El reparto profesional es coherente con el geográfico, pues eran los departamentos vinícolas del Languedoc: Hérault, Aude y Pyrénées-Orientales, los que reunían los mayores contingentes. En esas regiones, donde la propiedad estaba muy dividida, el sistema más frecuente era la contratación a ferme, mitad de la renta para el propietario y mitad para el colono, que se instalaba normalmente con la familia completa porque así contaba con mayor número de brazos para cultivar la tierra. Los mismos que antes de 1914 venían a trabajar estacionalmente, tienden luego a establecerse aprovechando ese tipo de contrato y las facilidades que daban las autoridades. De ese modo, la emigración se hacía sedentaria y se establecía con intención de arraigar. Al mismo tiempo, eso significaba que ese sector de la emigración vivía diseminada en cientos de pueblos, aldeas y fincas aisladas, lo que hacía muy difícil su control por las autoridades consulares.

Los que trabajaban de obreros o jornaleros urbanos habitaban naturalmente en los barrios o suburbios que correspondían a su condición social, de forma también dispersa y confundidos con la población local. Sólo algunos grupos vivían formando auténticas colonias, alojados por algún establecimiento minero o industrial importante. Entre los obreros predominaba la emigración individual, pero se recurría al reagrupamiento familiar en cuanto lo permitían las circunstancias. Como decía el cónsul español en Toulouse: «vienen los hombres primeramente, pero en cuanto encuentran trabajo y situación estable llaman a su lado a sus respectivas familias»?

Pero no todos los españoles tenían el mismo perfil socioprofesional. Aparte de estos modestos obreros y jornaleros, que componían la inmensa mayoría de la emigración en el Mediodía, había también algunos emigrantes acomodados. En una estadística realizada en el departamento de la Seine sobre la población activa de origen español, junto a 10.000 obreros y 11.200 individuos «sin profesión" que residían en los barrios industriales de Saint-Denis, Aubervilliers, Saint-Ouen, etc., aparecen 1.500 empleados en casas de comercio y en bancos, 1.000 profesiones liberales, algunos dirigiendo establecimientos financieros españoles en París, y 750 patronos, la mayor parte comerciantes, importadores de frutas - de origen mallorquín y levantino-, mercaderes de ganado, etc. ${ }^{10}$ Los propietarios de estas empresas comerciales, además, solían emplear dependientes ligados a sus patronos por relaciones familiares. Este grupo vivía sin

\footnotetext{
ros españoles, agrícolas en su mayor parte, aunque también se encuentran a trabajadores compatriotas nuestros en toda clase de oficios", AGA. Ministerio de Trabajo 75/23093.

9 Informe del cónsul en Toulouse, 1 de julio de 1925, AGA. Trabajo 75/23093.

10 «Les emigrés espagnols en France», informe confidencial del Bureau du Contrôle des étrangers, 15 de febrero de 1927, AD, Espagne, 133.
} 
duda con mayores garantías de seguridad y no necesitaba recurrir al auxilio de los consulados cuando la coyuntura laboral empeoraba. Eran siempre los jornaleros y obreros los que solicitan la hospitalización de beneficencia, o la repatriación por cuenta del Estado en cuanto dejaban de percibir su jornal por enfermedad o por el paro forzoso. Había incluso un reducido círculo de aristócratas españoles que mantenían una residencia en la zona turística del País Vasco francés, y que por sus características contrastaban sobremanera con el resto de sus compatriotas. Evidentemente, las demandas y el comportamiento de grupos tan diversos - círculos aristocráticos de Biarritz y Bayona, comerciantes instalados en las grandes ciudades, colonias de mineros de Saint-Etienne, obreros metalúrgicos de la periferia de París y jornaleros agrícolas del Sureste- no podían ser los mismos, ni tampoco la política aplicada por el Estado español hacia ellos. Incluso en la denominación se introducía una distinción entre los trabajadores españoles instalados en el sur de Francia y los residentes aristócratas en Biarritz o Bayona. Estos últimos según las fuentes, formaban una «colonia de extranjeros», no un núcleo de inmigrantes. El nivel de renta y la actividad profesional marcaban una frontera semántica: del término «inmigrante» quedaban excluidos quienes gozaban de altos ingresos. Por lo tanto, la condición de inmigrante no significaba simplemente trabajar en un país extranjero, sino cumplir una serie de requisitos preestablecidos que lo convertían en algo parecido a ser miembro de una casta.

Está claro que la gran masa de expatriados, la que dibujaba el perfil socioprofesional del emigrante español, la componían los peones, jornaleros y obreros sin cualificar empleados en los diferentes sectores. En general, eran los propietarios y arrendatarios franceses quienes reclamaban esa mano de obra que tanto escaseaba en el Mediodía francés, pero en su captación no parece haber tenido ninguna influencia el papel de los agentes reclutadores, los célebres «ganchos» que tanto preocupaban a la administración española y que jugaron sin duda un papel importante en la emigración hacia Latinoamérica. La emigración transpirenaica era espontánea, no organizada por compañías, agentes u organismos oficiales de recluta colectiva. Al menos en territorio español, porque en cuanto cruzaba la frontera, la administración francesa hacía todo lo posible por encuadrarla y orientarla según las necesidades de la economía nacional. El Ministerio de Agricultura francés creó durante la guerra una Oficina Nacional de Mano de Obra Agrícola encargada de atraer y organizar la recluta de grandes contingentes de trabajadores. En los años veinte se instalaron dependencias de ese organismo en Perpignan, Marignac y Hendaya con el fin de recibir los contingentes obreros españoles que cruzaban la frontera y de dirigirlos a los distintos departamentos del país según las demandas, preparándoles los contratos y la documentación necesaria. De manera que, aunque siempre estuvieron prohibidas en España las actividades de organizaciones dedicadas a la captación de emigrantes o a la recluta colectiva, la administración francesa nunca tuvo ningún obstáculo para proveerse de los contingentes necesarios gracias a la cercanía y la permeabilidad de la frontera. 
Un analista francés de la época ${ }^{11}$ valoraba al trabajador español por su «sobriedad legendaria» y por su aptitud "para los trabajos toscos y penosos» que los franceses rechazaban. Al mismo tiempo, señalaba como características negativas su suciedad y su incultura: cerca de la mitad de estos emigrantes eran analfabetos. En este sentido, su situación era mucho peor que la de los emigrantes italianos o belgas, pero no muy distinta a la que existía en la región del Levante español, de donde procedían la mayoría ${ }^{12}$. Estas circunstancias, y el hecho de que trabajaran habitualmente en las más bajas profesiones y las peor retribuídas, como terrassiers, peones de construcción, jornaleros del campo, canteros o mineros, no permitía que gozaran de una alta estima social. Como decía un inspector de emigración, «en el concepto público no son bien vistos, son siempre la sale race» ${ }^{13}$. A esta imagen negativa, asociada a su condición profesional y cultural, había que añadir el hecho de que eran extranjeros procedentes de un país neutral, lo que empeoraba más aún su condición ante los funcionarios franceses. En 1916 una comisión de la UGT se dirigió al Presidente del Consejo de Ministros, el Conde de Romanones, para denunciar que los obreros españoles en algunos puntos de Francia eran víctimas de malos tratos e injusticias por parte de las autoridades de ese país. La existencia de vejámenes y atropellos la confirmaron poco después los cónsules españoles. El de Burdeos señalaba muy pulcramente que: «sería inútil desconocer que existe en general en este distrito un espíritu de hostilidad latente contra todos los españoles, inherente a lo excepcional de las circunstancias por que atraviesa este país, que se manifiesta a cada paso y con el más insignificante motivo en el comercio diario de la vida en relación» ${ }^{14}$. Y unos años después todavía informaba el cónsul de Lyon de que «en las comisarías los tratan con los peores modales, emplean calificativos que no quiero ni puedo reproducir y siempre terminan por echarles en cara que vous n'avez pas fait la guerre, vous êtes de sales neutres... la actitud de algunos comisarios es intolerable, y bien sabe Dios que es injusta» ${ }^{15}$.

En estas circunstancias, no es extraño que los emigrantes buscaran protección juntándose con otros compatriotas, encerrándose en un círculo para crear un hogar que sustituyera al que habían dejado atrás. El número de sociedades españolas creadas en Francia al amparo de la ley de 1 de abril de 1898 empezó

11 Georges MAUCO, Les étrangers en France: leur rôle dans l'activité économique, 1932, citado por Yves DENECHERE, art. cit., p. 236

12. Vid Lorenzo Delgado y Antonio NiÑo, «Emigracion, enseñanza y nacionalidad en las relaciones hispano-francesas», Historia Contemporánea, 10 (1993), pp.51-101.

13 «Memoria del viaje realizado a Francia por el Inspector en viaje, Don Joaquín Cabronero». Madrid, 10 de diciembre de 1929, AGA, Trabajo, 75/23084.

14 El cónsul en Burdeos al Ministro de Estado, Burdeos, 29 de enero de 1916. AGA.Asuntos Exteriores, 1688.

15 «Contestación al formulario de preguntas», consulado de Lyon, 21 de julio de 1924. AGA, Trabajo, 75/23093. 
a crecer aún antes del conflicto europeo ${ }^{16}$. Sin duda es éste un reflejo común a todos los emigrantes, que explica el fenómeno del asociacionismo étnico. El emigrante no es un cosmopolita, no es alguien que viaja impulsado por la curiosidad o por la inclinación a descubrir formas de vida diferentes, sino por el deseo de procurarse mejores condiciones de vida. El contacto con otra cultura, con otro medio social, no se percibe como un beneficio sino como un coste necesario que hay que intentar reducir lo más posible. El asociacionismo es la respuesta natural a esa necesidad de mantener una vida de relación social en un medio extraño, además de una respuesta a la falta casi absoluta de protección social, como luego veremos.

A pesar de todo ello, en el caso de la emigración española en Francia son numerosos los testimonios de cónsules y prefectos señalando que los obreros españoles carecían del sentido y del espíritu de asociación, que eran individualistas y reacios a formar organizaciones de ayuda mutua. El cónsul de Toulouse, por ejemplo, informaba de que «en esta región en general el español da muestras de su peculiar y característico individualismo. Viven en general independientes los unos de los otros y han fracasado cuantas asociaciones o centros han intentado fundarse» ${ }^{17}$. El hecho de que las asociaciones españolas fueran menos numerosas y menos sólidas que las que creaba, por ejemplo, la emigración italiana, tiene sin duda otra explicación que la de sus características raciales o temperamentales. En primer lugar, el asociacionismo es un recurso que sólo está al alcance de quienes se instalan de forma perdurable, no de aquellos que han cambiado su residencia de forma pasajera, como era el caso de la mayoría de los braceros agrícolas y obreros. El carácter temporal, cuando no estacional, de gran parte de esa emigración obrera, generaba un trasiego constante que hacía muy difícil el arraigo y la asociación. A ello se añadía la dispersión, especialmente acusada en el caso de los braceros agrícolas. Eso explica que en las sociedades de emigrantes que llegaban a constituirse estuvieran normalmente sobrerrepresentados los comerciantes y empleados de las zonas urbanas. Otra dificultad era la diversidad regional de su procedencia, que a veces generaba enemistades, o simplemente dificultades de comunicación entre ellos, como señalaba un inspector de migración: «los distintos dialectos que hablan nuestros emigrados trae por consecuencia que mallorquines, catalanes, valencianos, castellanos, aragoneses y vascos no puedan comprenderse más que haciendo uso del lenguaje de la tierra extraña» ${ }^{18}$. Por último, y al contrario que en América, no había prácticamente potentados y acaudalados comerciantes que pudieran con sus medios de fortuna prestar ayuda a las obras de beneficencia o de enseñanza, y por lo mismo faltaban personas de pronunciada significación so-

16 Intérieur, étrangers en France. Sociétés espagnoles, 1909-1914. AD, Serie «C» Administrative, 1908-1940, 252.

17 Informe del cónsul en Toulouse, 1 de julio de 1925, AGA, Trabajo, 75/23093.

18 «Memoria sobre la creación de Patronatos en Francia, por Fernández Flórez, inspector de emigración en viaje», 11 de diciembre de 1929, AGA, Trabajo, 75/23084. 
cial y posición económica desahogada que quisieran aportar su concurso a las instituciones colectivas a cambio de prestigio y ascendiente sobre sus connacionales. Los comerciantes fruteros, el único grupo importante de españoles poseedores de bienes de fortuna, no solían ser elementos activos en la vida de la colectividad, y ello se debía, según el cónsul de Toulouse, a que: «toda preocupación de carácter patriótico o altruista les es completamente ajena. Son incapaces del menor sacrificio en aras de la colectividad española, algunos de ellos son de ideas separatistas y los mejores viven entregados por completo a sus negocios, única finalidad de su existencia» ${ }^{19}$.

Todo ello ponía obstáculos al asociacionismo étnico, pero no impidió que fuera creciendo paulatinamente el número y el tamaño de las agrupaciones creadas por la emigración. A partir de la segunda mitad de los años veinte, sobre todo, la apreciación cambia y se habla de que «existe hoy como un despertamiento, comprensión y anhelo innegables en nuestras colonias de crear sociedades de socorros mutuos y centros de reunión", lo que para el embajador era un dato muy positivo "por ser base fundamental para el mejoramiento material y la ayuda inmediata indispensable a las colonias, así como para mantener en ellas viva la llama del sentimiento patrio y el cariñoso respeto a las instituciones seculares ${ }^{20}$. Según una publicación del Ministerio del Interior francés, en 1927 había en Francia treinta y cuatro sociedades filantrópicas españolas que se dedicaban a proteger a los emigrantes. Pero un recuento que realizó la embajada española en 1928 elevaba esta cifra a más de cien asociaciones sólo en la Francia metropolitana, muchas de las cuales no estaban inscritas en los consulados respectivos.

El grado de organización de las colonias era muy variable según los lugares: excelente en las demarcaciones consulares de Perpignan y Marsella, muy escaso en las demarcaciones de Burdeos, Lyon, y París, prácticamente inexistente en las de El Havre o Saint Nazaire. La mayoría de las asociaciones españolas eran sociedades de socorros mutuos que proliferaban en los departamentos de Aude, Gard y Hérault, en las jurisdicciones de Toulouse y Marsella, y en mucho menor número en el Rhône y la Loire. Se trataba de pequeñas agrupaciones de entre una veintena y un centenar y pico de socios, que se mantenían precariamente con las cuotas de sus socios, donativos y fiestas benéficas. Su proliferación se explica fundamentalmente por la ausencia de un convenio de asistencia social y de hospitalización que proporcionara a los trabajadores españoles la protección más elemental. Las familias no podían recibir la asistencia de las instituciones del país cuando enfermaba alguno de sus miembros porque para entrar en el hospital local tenían que hacer un depósito de 400 a 600 francos, según la enfermedad, que garantizara el pago de sus gastos. Ni el depósito ni los gastos estaban al alcance de los que vivían de un jornal. Cuando se trataba de un caso urgente y de indigencia extrema, y siempre que el interesado estu-

19 Informe del cónsul en Toulouse de 9 de agosto de 1933, AGA, Trabajo, 75/23084.

20 Despacho del embajador en París, 31 de agosto de 1928, AGA, Trabajo, 75/23084. 
viera debidamente inscrito, el consulado español sufragaba los gastos mientras tuviera fondos para ello, lo que no duraba mucho dado el elevado número de casos que se presentaban. En esta situación, formar mutualidades se convertía en una auténtica necesidad, ya que era la única manera de garantizar una mínima prestación sanitaria y farmacéutica a cambio de una cotización de cinco o seis francos mensuales. El cónsul destinado en Cette lo explicaba de una forma muy plástica: «ni el afán de cultura, ni el patriotismo, ni las afinidades regionales, han tenido aquí virtualidad para unir a nuestros compatriotas. Lo que les ha llevado y les mantiene unidos es un sentimiento más primitivo, más elemental: el temor al abandono en caso de enfermedad, el temor a la miseria, secuela del dolor físico. La imposibilidad de hallar acceso a los hospitales franceses les ha llevado a vencer el feroz individualismo español y esto, en proporciones más bien modestas, pues el número de los no asociados es todavía enorme y constituye, sin duda alguna, la mayoría» ${ }^{21}$.

Pero además de estas pequeñas y numerosas agrupaciones dedicadas al socorro mutuo, había otras asociaciones de gran tamaño, de carácter mixto, que cubrían un amplio abanico de atenciones - realizaban labores de beneficencia y funciones recreativas además de la asistencial-, que se localizaban en importantes ciudades y que poseían edificios propios que las hacían bien visibles. En Burdeos funcionaba desde 1920 el «Solar Español», poderosa institución fundada por un comité de señoras presidido por la Condesa de Gavia, y otro de caballeros dirigido por el Duque de Miranda, y ambos con presidencia de honor de los Reyes Alfonso XIII y doña Victoria. Un español benemérito proporcionó el edificio y los terrenos: $3.000 \mathrm{~ms}^{2}$ entre las calles Dubourdieu, Pauline Kergomard y la plaza Simiot. Lo dirigía un Patronato presidido por el Duque de Miranda y, como institución declarada de utilidad pública, recibía una subvención del Ministerio de Estado español. En sus estatutos se establecía "como fin primordial y básico contribuir a la protección moral de los españoles e hispano-americanos necesitados en Burdeos y especialmente a la conservación, desarrollo y complemento de las obras de acción religiosa, social, instructiva y benéfica». Entre sus prestaciones se contaba un amplio abanico de servicios: escuelas elementales para los niños, complementarias de la educación que recibían en los colegios franceses, y nocturnas para los adultos, con enseñanza de idioma, historia, geografía y religión; un consultorio y dispensario médico, gratuito para los indigentes, dirigido por doce facultativos de diferentes especialidades y atendido por religiosas; una bolsa de trabajo; una oficina de protección legal; organización de homenajes a la vejez; colonias de vacaciones de niños en Fuenterrabía, etc. El Solar, que estaba dirigido por religiosos, era considerado parroquia de españoles y en él se celebraba culto regularmente. Se trataba, en fin, de una poderosa institución, mimada por las autoridades espa-

21 Despacho del cónsul de Sête al Inspector General de Emigración, 24 de enero de 1930. AGA, Trabajo, $75 / 23084$. 
ñolas y con un fuerte sesgo paternalista, que contrastaba con el muy escaso desarrollo mutualista en el departamento de la Gironde. Para una población emigrante allí residente que se estimaba en unos 30.000 obreros españoles, sólo se conocen dos sociedades de socorros mutuos para obreros: «La Unión Española» y «La Amistad de Cenon y de Floirac».

Algo similar ocurría en la periferia de París. También allí se había creado en 1922 una institución de inspiración religiosa: el Real Patronato de Santa Teresa de Jesús, en Saint Denis, dedicado al cuidado espiritual de los obreros y la educación religiosa de sus hijos, además de mantener un dispensario para consultas médicas. Contaba también con el apoyo de las autoridades españolas y una subvención de la embajada. En la misma localidad, «el corazón comunista de la capital» según el embajador, funcionaba también desde 1926 una asociación mutualista de carácter católico y formada por obreros «ortodoxos», llamada el Foyer des Espagnols, que atendía sus necesidades sanitarias en el mismo dispensario del Real Patronato ${ }^{22}$. En el resto de París y su región había además una Sociedad de Socorros Mutuos en Vitry — 40 miembros-, La Casa de España, con fines recreativos, la Asociación Española e Hispanoamericana, dos clubs deportivos, La Casa Catalana y la Asociación para el Desarrollo de la Cultura Catalana. Poca cosa para la gran población obrera que se concentraba en sus barrios industriales. A los propios servicios del Ministerio del Interior francés les parecía que «estos emigrados no parecen experimentar la necesidad de fundar entre ellos círculos, ni de asociarse con un fin político o de mutua ayuda» ${ }^{23}$.

Un caso modélico, según el embajador y el cónsul de Perpignan, era el Centro Español de los Pirineos Orientales que funcionaba en esa ciudad desde 1913, sin recibir ningún apoyo oficial, aparte del concurso eficaz e interesado del cónsul. El Centro contaba a finales de los años veinte con unos 2.000 socios, en su mayoría obreros - que con sus familias representaban a 10.000 personas-, y «de un credo patriótico de toda pureza», es decir, «sin connotaciones catalanistas» a pesar de que casi todos sus socios eran de origen catalán y no faltaron los intentos de convertirlo en un Casal catalán. En 1921 se fundió con otras dos sociedades: la Colonia Española y Unión Ibérica, de manera que centralizaba eficazmente todas las atenciones de los 15.000 españoles de la ciudad de Perpignan, y de otros 25.000 que se repartían por el Departamento gracias a las doce sucursales que tenía en otras tantas localidades. El Centro era una sociedad mutualista que contaba con un edificio propio de $620 \mathrm{~ms}^{2}$ en el centro de la ciudad, donde estaba instalado el dispensario, la caja de vejez e invalidez, un café, baile, coro, grupo dramático, billares, escuelas nocturnas, biblioteca y club atlético ${ }^{24}$. Realizaba además labores de beneficencia con los numerosos españoles transe-

22 Ver el artículo de Ana FERnÁndeZ ASPERILla publicado en este mismo número.

23 «Les emigrés espagnols en France», informe confidencial del Bureau du Contrôle des étrangers, 15 de febrero de 1927, AD, Espagne, 133.

24 Vid. informes del cónsul en Perpignan de 3 de diciembre de 1928 y 10 de agosto de 1933 , AGA, Trabajo, 75/23084.

Hispania, LXII/2, núm. 211 (2002) 433-482 
úntes que pasaban por la ciudad. Para el cónsul el Centro tenía un valor añadido por su situación junto a la frontera y porque, según él, «constituye una apreciable barrera para contrarrestar los manejos de ciertos elementos faciosos», en especial la labor del Casal catalán que funcionaba en la misma ciudad.

Otro caso excepcional era el Centro Instructivo Obrero Español de Bayona, creado en 1919 por un grupo de obreros españoles, sin connotaciones oficiales ni religiosas. Llegó a tener más de cuatrocientos socios, y funcionó muy activamente en los años veinte, organizando una selecta biblioteca y conferencias periódicas de intelectuales franceses y españoles. Este Centro fue el promotor de la fundación en Bayona de las primeras escuelas españolas en territorio francés, proyecto que hizo suyo el Gobierno español pero que no se llevó a cabo por la intransigente oposición de las autoridades francesas. Esta asociación es un caso señalado porque, siendo una agrupación estrictamente obrera, tenía como objetivo principal la instrucción cultural de sus miembros, mientras que la atención mutualista sólo era un apéndice de su actividad educativa.

Estas eran las más importantes. Ninguna de estas sociedades recibía subvenciones económicas del Gobierno español, salvo las de carácter religioso que funcionaban en Burdeos y París, y ello a pesar de las continuas solicitudes de ayuda, encauzadas por los consulados. Este «simpático e interesantísimo" movimiento asociativo, en expresión del embajador Quiñones de León, muestra la existencia de una emigración relativamente asentada y de larga duración, pues sólo cuando los emigrantes aceptan la idea de permanecer fuera de España mucho tiempo comienzan a unirse de forma espontánea en organizaciones basadas en la solidaridad nacional. Su razón de ser era sin duda la función asistencial — constitución de un fondo común alimentado por cuotas mensuales para garantizarse las prestaciones sanitarias-, a la que se añadía a veces el funcionamiento como oficinas de defensa legal y laboral, centros de instrucción y de capacitación, lugares de recreo, etc. En la práctica se convertían en espacios de sociabilidad y de autodefensa de su identidad cultural frente a las prácticas a menudo excluyentes de la sociedad de acogida, una suerte de refugio que facilitaba la vida en el país receptor. Estas asociaciones, además, canalizaban de forma natural las demandas de los emigrantes y sus dirigentes actuaban como los únicos interlocutores ante las autoridades consulares españolas. Estas tenían un interés evidente en controlarlas, porque entendían que eran un medio eficaz de mantener las costumbres y los valores morales españoles y una barrera contra la contaminación de la población autóctona, es decir, un instrumento para preservar la nacionalidad de los emigrantes.

\section{LA POLÍTICA DEL ESTADO ESPAÑOL}

La actitud general de las clases dirigentes españolas ante la emigración de principios del siglo XX consistía en tratarla como un problema, cuando no 
como una lacra nacional que había que combatir desde el Estado por todos los medios, aunque siempre respetando el principio liberal del derecho de todo individuo a emigrar. La primera preocupación de las autoridades era que la emigración no se convirtiera en una vía para evadir responsabilidades penales, o para librarse del servicio militar o su sustitutivo la redención en metálico. Algunos cónsules destacados en Francia señalaban, por ejemplo, que la abundancia de varones entre 19 y 21 años en sus distritos sólo podía deberse a que gran parte de ellos eran prófugos y desertores del ejército español. La Embajada de España, por su parte, presionaba constantemente para que se prohibiera la estancia de desertores españoles en los departamentos fronterizos, objetivo siempre frustrado porque las autoridades francesas alegaban que ninguna prescripción de derecho internacional justificaba la adopción de esa medida, ni existía ninguna convención sobre intercambio de desertores del ejército. Su doctrina era que «cada Estado es totalmente libre para acoger en su territorio a los desertores de nacionalidad extranjera y sigue siendo el único juez de las normas de policía que conviene aplicar a estos individuos» ${ }^{25}$.

Existía pues una emigración ilegal o clandestina que el Estado intentaba reprimir por todos los medios porque lo consideraba su primera obligación. Pero había también una preocupación más general por la sangría que suponía la expatriación de población en edad activa y por el peligro de despoblamiento que, supuestamente, corría el país. Hay que recordar que la emigración masiva de españoles que se inició a finales del siglo XIX, especialmente hacia Latinoamérica, coincidió con el debate planteado por el Regeneracionismo sobre las causas del atraso español, y que este movimiento de renovación nacional interpretó el fenómeno de la emigración como un signo más de la decadencia del país. A la tradicional preocupación por la pérdida de mano de obra y el peligro de la «despoblación», se añadía ahora el desprestigio que suponía para la nación la salida masiva de trabajadores en busca de oportunidades laborales en el extranjero. La emigración era una vergüenza nacional que se pintaba habitualmente en los medios de comunicación con los tintes más negros, asociándola con explotación, abuso y humillación. En un muestreo realizado en la prensa española de 1918, por ejemplo, aparecen más de 200 artículos referidos expresamente a la emigración a Francia, con títulos tan expresivos como los siguientes: «Exportación de carne humana», en La Epoca; «El peligro de la emigración», en El Día Gráfico de Barcelona; «Una emigración ruinosa», en Diario de Galicia de Santiago; «iTristes levas!», en El Pueblo Católico de Jaén; "Cómo tratan a los españoles en Francia», en El Correo del Norte de San Sebastián; "La hemorragia de la emigración», en El Mundo; «iA Francia!: La Emigración», en El Pueblo Católico; «Españoles injuriados y maltratados en Francia: ¿Es posible?», en El Liberal; «Tristísima odisea de numerosos españoles», en La Prensa;

25 «Note au sujet du Régime des Étrangers résidant à proximité des frontières italienne et espagnole», 22 noviembre 1924, AD, Espagne 272.

Hispania, LXII/2, núm. 211 (2002) 433-482 
«Los escándalos de la emigración», en El Día Gráfico; «El escándalo de la emigración», en El Debate; «Los que emigran a Francia: Triste odisea de unos obreros», en La Región de Orense; "Tráfico infame: en defensa de los obreros españoles", en La Independencia de Almería ${ }^{26}$.

La consecuencia de ese estado de opinión y de esa preocupación por la suerte de sus connacionales fue que se estableciera en las leyes sobre la materia la prohibición expresa de cualquier tipo de propaganda para fomentar la emigración, la recluta de emigrantes en territorio español y la contratación colectiva. El Estado español no podía prohibir la emigración - aun cuando la legislación contemplaba tal posibilidad en circunstancias de interés público-, pero perseguía penalmente el tráfico de emigrantes. Se consideraron actividades delictivas las gestiones de los agentes 0 "ganchos» que se dedicaban a esa «inicua industria", y se otorgó a los inspectores de emigración funciones casi policiales, de manera que los problemas de la emigración se asociaban habitualmente a las cuestiones de policía y persecución de actividades criminales ${ }^{27}$.

Desde el punto de vista legislativo, la respuesta del Estado liberal español al fenómeno migratorio se plasmó en la Ley de Emigración de 21 de diciembre de1907, que fue elaborada y aprobada durante el Gobierno conservador de Antonio Maura ${ }^{28}$. Esta ley se inspiraba en la labor legislativa de otros países europeos - sobre todo en la ley italiana de emigración de 1901-, e introducía, como principal novedad, la preocupación por lo que entonces se denominaba la «cuestión social». El objetivo de la ley ya no era únicamente fiscalizar la emigración - evitar que los súbditos del reino se libraran del servicio militar o que eludieran sus responsabilidades con la justicia - sino también «tutelar» a los emigrantes, garantizarles la protección del Estado para que los trabajadores no fueran víctimas de traficantes, empresas y compañías navieras que se lucraban a su costa. La ley pretendía ordenar el fenómeno migratorio que había surgido espontáneamente y que estaba adquiriendo proporciones masivas, pero también creaba las condiciones para que el Estado se convirtiera en un agente importante en ese juego. De hecho, la ley de 1907 diseñó una estructura administrativa con dos áreas de competencias: una interior y otra exterior. La exterior se apoyaba en la red consular española mientras que la interior estaba dirigida por el Ministerio de Gobernación. Como desarrollo de la ley se creó,

26 Vid. «Indice de libros y artículos de revistas y periódicos que se han consultado y catalogado como elementos de estudio o de orientación en las cuestiones relacionadas con la emigración posterior a la guerra», Boletín del Consejo Superior de Emigracón, 1918, pp. 29-35.

27 Algo muy similar a lo que ocurre hoy día cuando las noticias sobre la inmigración se sitúan en las páginas de sucesos o se refieren a la persecución de las «mafias» o redes clandestinas dedicadas al tráfico de personas.

28 Vid. PereZ-PRENDES, José Manuel, El marco legal de la emigración española en el constitucionalismo, Gijón, Fundación Archivo de Indianos, 1993. 
un año después, el Consejo Superior de Emigración ${ }^{29}$, con sus Juntas locales de emigración en los principales puertos y su cuerpo de inspectores. En 1911 esos organismos pasaron a depender del Ministerio de Fomento, y luego al de Trabajo. De esta forma el Estado se dotó de los medios imprescindibles para intervenir en un fenómeno sobre el que fue asumiendo cada vez más responsabilidades.

Esta legislación y esta estructura administrativa se dirigía en principio a ordenar el control de los emigrantes y la inspección de navieros y compañías de transporte, con el fin de ofrecer unas mínimas garantías, pero poco a poco se utilizó también para entorpecer la emigración por acumulación de trabas burocráticas. Bien es verdad que la ley se basaba en el reconocimiento expreso de la libertad de emigración - cuestión sobre la que giraron los debates en el Parlamento-, pero ello no era incompatible con la intención de poner todas las cortapisas posibles a lo que se consideraba una sangría nacional. La administración no impedía la emigración de quienes estaban determinados a ello pero, alegando razones «humanitarias y de tutela», ponía todo tipo de obstáculos: se habilitaron sólo ciertos puertos para el embarque, se creó un pasaporte especial de emigrantes, y se exigía efectuar un depósito de garantía por los gastos de repatriación. A su vez, para obtener el pasaporte de emigrante era necesario presentar un contrato de trabajo individual y visado por los cónsules de los lugares donde se fuera a trabajar ${ }^{30}$. Es evidente que todas estas trabas dificultaban la emigración pero no la impedían. Lo peculiar de la emigración a Francia es que todas estas medidas ni siquiera surtían un efecto disuasivo porque, dadas las características del destino, no podían aplicarse en la práctica. En primer lugar porque era una emigración espontánea que no dependía de la recluta de agentes ni de la propaganda de compañías navieras; y en segundo lugar porque la salida no se producía por los puertos sino por las fronteras terrestres, y en ellas no se exigía el pasaporte de emigrante, ni contrato de trabajo o «carta de llamada», ni depósito de garantía. La administración acabó considerándolo un éxodo inevitable "porque es imposible poner puertas a los mil pasos practicables que los Pirineos tienen» ${ }^{31}$.

Curiosamente, la ley de 1907 sólo reputaba como emigrantes a los españoles que se dirigían a países de América, Asia u Oceanía con pasaje marítimo de tercera clase. No consideraba tales, por consiguiente, a los españoles de modesta condición económica que se trasladaban a países europeos. Esa definición se 1908.

29 Por el Reglamento que desarrollaba la ley, promulgado como Real Orden de 30 de abril de

30 Por Decreto de 24 de enero de 1930 se suprimía la carta de identidad de emigración establecida por R.D. de 23 de septiembre de 1916, estableciéndose en su lugar el pasaporte de emigrantes, expedido por los Gobiernos Civiles, para todos aquellos que por causa de trabajo se dirijan a países de Ultramar, Francia, Portugal y países del Norte de Africa, inclídas las zonas del Protectorado de Marruecos.

31 Informe de la sección tercera de la Dirección General de Emigración, acerca de las cuestiones que plantea la presencia de la mano de obra española en territorio francés, 4 de octubre de 1926. AGA, Trabajo, $75 / 23082$.

Hispania, LXII/2, núm. 211 (2002) 433-482 
corrige en la ley de 20 de diciembre de 1924 , donde ya se considera emigrante a todo aquél que, por causa de trabajo, se dirija a cualquier país extranjero, y no tan sólo a los que vayan a Ultramar. Eso nos indica que, durante mucho tiempo, la emigración a Francia no fue considerada plenamente como tal, primero porque esa emigración había sido hasta entonces fundamentalmente estacional, y luego porque las circunstancias bélicas hacían pensar que la avalancha de los años 1915-1919 tendría también un carácter temporal. El hecho es que el Estado español contempló con una sorprendente indiferencia la salida masiva de trabajadores hacia Francia durante la Guerra Europea y en años posteriores, no consideró necesario adoptar ninguna medida al respecto, y sólo empezó a plantearse esa realidad como un problema cuando su número había alcanzado ya un volumen considerable.

Por lo tanto, hasta mediados de los años veinte no aparece una preocupación entre las autoridades españolas por la situación de la emigración económica en Francia. Otra cosa es la inquietud que tradicionalmente provocaba la emigración política instalada desde antiguo en el país vecino. Eran constantes las reclamaciones de la Embajada en París para que no se permitiera a los revolucionarios españoles hacer actos de propaganda ni organizar reuniones políticas en los departamentos fronterizos. Según las autoridades francesas, sin embargo, su legislación y sus tradiciones de hospitalidad garantizaban las libertades públicas de los extranjeros, aunque no el ejercicio pleno de los derechos políticos. Es decir, que un extranjero no podía ser perseguido por sus ideas políticas, pero tampoco podía dirigir un periódico en Francia, por ejemplo, ni administrar un sindicato, y sus asociaciones podían ser disueltas discrecionalmente por el Gobierno. Por otro lado, cualquier extranjero podía ser expulsado y puesto en la frontera «si amenaza el orden público o perturba la tranquilidad de la población ${ }^{32}$, definición lo suficientemente ambigua como para permitir un uso discrecional de esta potestad según las circunstancias. Cuando las relaciones con la Dictadura de Primo de Rivera lo hacían conveniente se utilizaba esta medida contra los agitadores españoles, y así, de 1921 a 1927 fueron expulsados un total de 92 españoles por sus actividades políticas, otros fueron invitados a cesar en sus tareas juzgadas «incorrectas», y 217 fueron expulsados como consecuencia de condenas judiciales ${ }^{33}$. Por lo demás, la policía francesa vigilaba estrechamente los comités y células donde se agrupaban algunos centenares de «elementos turbulentos adeptos a las teorías comunistas o anarquistas», y es conocido el hecho de que, durante la Dictadura de Primo de Rivera, la embajada de España en París estableció un servicio de espionaje y de persecución contra los emigrados políticos con la ayuda de varios jefes de policía franceses.

32 «Note au sujet du Régime des Etrangers résidant à proximité des frontières italienne et espagnole», 22 noviembre 1924, AD, Espagne 272.

33 «Les emigrés espagnols en France», informe confidencial del Bureau du Contrôle des étrangers, 15 de febrero de 1927, AD, Espagne, 133. 
Desde el punto de vista de las autoridades españolas, por lo tanto, la emigración se percibía como un peligro y sobre todo como una sangría nacional: se perdían hombres para su ejército, población para la grandeza del país y brazos para su economía. El análisis económico del problema no era el más frecuente, pero también entraba en consideración. Algunos funcionarios españoles se entretenían en calcular la pérdida de contribuciones que sufría el Estado por las actividades económicas de los emigrantes que no cotizaban en España. Otros protestaban de que el Estado tuviera que dedicar sumas de dinero a la atención de sus ciudadanos en el extranjero, cuando era otro el país que se beneficiaba de su trabajo. Un inspector de emigración sostenía que «debe adoptarse fatalmente el criterio de considerar nuestra emigración - con todos los respetos debidos a la dignidad humana- como un producto de exportación y como tal convencernos de que tenemos una fuente de riqueza que hay que valorizar en el mercado colocándola en las condiciones y a la cotización que exijamos y no al precio que quieran pagarnos. Hasta hoy la hemos venido vendiendo mal y lo más grave, poniendo dinero encima» ${ }^{34}$. En todo caso la emigración se consideraba siempre una pérdida neta para el país. Todavía no se contabilizaban, como haría posteriormente el Régimen franquista, los beneficios económicos que la emigración reportaba en forma de remesas de divisas. Mucho menos se podía considerar entonces, como tiende a hacerse hoy, que la emigración era un mero efecto del proceso de modernización de una sociedad y una señal, por lo tanto, de desarrollo. Hay quien destaca hoy día que la emigración era una consecuencia de la necesaria desruralización, que adquiría en parte la forma de emigración internacional. La historiografía reciente, al contrario que las visiones pesimistas de principios de siglo, tiende a interpretar las migraciones simplemente como una estrategia de movilidad económica y social ascendente que las familias campesinas asumen racionalmente - la emigración como «una industria de pobres»- y que son por lo tanto un efecto y un factor de modernización, económica y social, de las viejas sociedades agrarias de procedencia. Más aún, en el colmo de la visión «optimista» del fenómeno, hay autores que pueden llegar a explicar el proceso migratorio sencillamente como un desplazamiento internacional de capital humano, impulsado naturalmente por las fuerzas del mercado, que tiene el efecto de redistribuir más eficazmente los factores de producción en el mundo capitalista ${ }^{35}$.

También en este aspecto de sus efectos económicos se hacía una distinción importante entre la emigración a ultramar y la continental. Mientras que la primera se consideraba duradera «y a la postre se traduce casi siempre en desarraigo definitivo de la patria y subsiguiente pérdida para su demografía, la segunda es temporal, es transitoria, y con frecuencia... de corta duración y muy

34 «Memoria ..., Don Joaquín Cabronero». 10 de diciembre de 1929, AGA, Trabajo, 75/23084.

35 Vid. SANCHeZ ALONSO, Blanca, Las causas de la emigración española, 1880-1930, Madrid, Alianza, 1995, p. 48.

Hispania, LXII/2, núm. 211 (2002) 433-482 
provechosa para el mejoramiento de sus aptitudes profesionales» ${ }^{36}$. Para los funcionarios de la Dirección General de Emigración, la marcha de trabajadores a Francia era preferible porque se hacía no con la perspectiva de la integración sino con la del retorno en un plazo no muy largo. Además, el traslado a una economía más avanzada como la francesa podía equipararse, según ellos, a unos cursos de perfeccionamiento profesional de obreros industriales en el extranjero, que además salían gratis, con lo que podrían ahorrarse las subvenciones oficiales que se concedían al Patronato oficial de Obreros Pensionados en el Extranjero que había establecido el Gobierno. Curioso razonamiento que refuerza la impresión de que el cálculo de las consecuencias económicas de la emigración se hacía contemplando sus efectos inmediatos sobre el presupuesto, y no su repercusión en el conjunto de la economía nacional. Del mismo modo, esos análisis nos indican una vez más la existencia de un prejuicio favorable hacia la emigración continental respecto a la que se dirigía, mayoritariamente aún, hacia Ultramar.

Pero esta argumentación se invertía cuando en vez de los efectos económicos se abordaban las consecuencias culturales de la expatriación. Aquí Ultramar recuperaba la ventaja, porque se suponía que en América esos emigrantes revivificaban los vínculos de sangre históricos que unían a la vieja metrópoli con sus antiguas colonias - y servían así quizás de seguro cimiento para el desarrollo del comercio con esas repúblicas-, pero en Francia ese torrente de nacionales que se instalaban y se asimilaban en la nueva sociedad se perdía sin provecho alguno. Desde el punto de vista de la nacionalidad y de la cultura hispánica, era una pérdida absoluta y definitiva, que se prolongaba en sus descendientes.

Aparece así el fantasma de la asimilación por el extranjero de los hijos de la patria. Esta preocupación, novedosa entonces, obedece a un cambio de sensibilidad en la opinión pública y la prensa que, a mediados de los años veinte, promueve una auténtica campaña para llamar la atención sobre el peligro de desnacionalización de los millones de españoles residentes en América, y los cientos de miles en Francia y sus colonias del norte de África. Se pedía al Gobierno que, si no era capaz de reducir la emigración creando oportunidades de trabajo en el país, al menos creara escuelas, sociedades y círculos para mantener los lazos entre la sociedad de origen y sus nacionales en el extranjero ${ }^{37}$. Pero el problema de la asimilación tenía un doble aspecto: legal y cultural, que exigían tratamientos diferenciados. Desde el punto de vista legal, las autoridades españolas estaban naturalmente interesadas en conservar la nacionalidad española de sus numerosos emigrantes, y se mostraban muy preocupadas porque las legislaciones de algunos países provocaban la desnacionalización rápida de los

36 Informe de la sección tercera de la Dirección General de Emigración, acerca de las cuestiones que plantea la presencia de la mano de obra española en territorio francés, 4 de octubre de 1926. AGA, Trabajo, 75/23082.

37 Vid. «La natalidad y la emigración. Problemas de Francia», El Imparcial, 17-XI-1926, y diversos artículos en El Sol, La Correspondencia Militar, La Epoca. 
españoles. En México una ley había recortado el derecho de propiedad de los extranjeros, y en Cuba otra ley limitaba al $25 \%$ el número de asalariados extranjeros permitidos en cualquier industria o explotación. El Gobierno de Primo de Rivera estudió la posibilidad de recurrir a un sistema de defensa ya ensayado en Alemania con la ley Delbrück de 1913: sin perder su nacionalidad de origen, los españoles que residieran en América podrían, con la autorización del Ministerio de Estado, adquirir momentáneamente la nacionalidad del país donde se encontraran, conservando sus derechos en la patria de origen ${ }^{38}$. El problema sería resuelto por la Segunda República estableciendo en la propia constitución la posibilidad de llegar a acuerdos de doble nacionalidad con las repúblicas hispanoamericanas. En el caso de la emigración a Francia esta posibilidad ni siquiera se planteó, seguramente porque no se consideró posible que pudiera ser aceptada, aunque no dejó por ello de inquietar a los representantes diplomáticos franceses ${ }^{39}$.

Pero el problema no tenía únicamente un aspecto legal. El vínculo nacional era desde luego un vínculo de ciudadanía, pero también un vínculo espiritual y cultural, y este aspecto era el que más peligro corría en el caso de la emigración a Francia. En un memorándum redactado por Américo Castro y dirigido al Ministerio de Estado en 1921 se perfilaba así el problema:

«La fuerte corriente emigratoria que existe en España, va creando, en todos los países de América, en algunos de Europa y en algunas regiones de Africa, núcleos numerosos de nacionales que residen de modo permanente fuera de su patria. El Estado español tiene el deber de prestarles la debida ayuda y de impedir que se rompa el lazo espiritual que debe unirles con la patria. Si en la América española puede y de hecho existe el peligro de la absorción política y la pérdida de la primitiva ciudadanía, la comunidad de lengua y de cultura entre España y aquellas Repúblicas, deja siempre vivo ese sentimiento de origen y de hermandad. Pero en las colonias españolas constituidas en otras naciones - por ejemplo, en Francia: especialmente en Burdeos, Toulouse y Argelia - el peligro se agrava con la casi inmediata pérdida de la lengua patria. La primera generación nacida en Francia o llevados allá en los primeros años, conserva, sí, el español como lengua de familia, pero adquiere el francés como lengua de cultura. Se nos ha señalado por personas que atienden a la colonia obrera de Burdeos el hecho de que muchos niños españoles que siguen hablando el español, no saben leerlo ni escribirlo, porque aprenden a leer y a escribir en francés. Quiere esto decir que esa generación rompe ya toda unión con su patria, y la separación es tanto más profunda y fácil cuanto que les falta en su propio hogar, y no por nada censurable, sino porque sus padres pertenecen a las clases más humildes y carecen de aquella cultura más elemental indispensable para mantener vivo, en la emigración, el sentimiento de patria, todo estímulo que cree y reconforte ese sentimiento que se va apagando en ellos»40.

38 Vid. «Hispano-americanismo práctico», El Noticiero del Lunes, 22-II-1926, p. 5.

39 Despacho del embajador de Francia en Madrid de 23 de febrero de 1926, AD. Espagne 133.

40 "La necesidad de plantearse y realizar un programa de política cultural fuera de España», memorándum de la Oficina de Relaciones Culturales, s.f. AMAE, R-1380/26. Sobre la labor de esta dependen-

Hispania, LXII/2, núm. 211 (2002) 433-482 
Es decir, que si grave era el peligro de «absorción política» que implicaba la pérdida de la ciudadanía española, más grave le parecía aún al asesor del Ministro la pérdida del «sentimiento de patria», ese vínculo espiritual que se manifiesta sobre todo en la posesión de «la lengua patria». Y esta inquietud no era exclusiva de un intelectual como Castro que desde las alturas se dedicaba a proponer remedios para salvar al país, sino que se refleja también en las informaciones que tenemos sobre lo que preocupaba a los propios emigrantes. El cónsul de Perpignan, por ejemplo, manifestaba que: «numerosos son los españoles que se lamentan de no poder dar ni educación española a sus hijos, ni tan solo el conocimiento del lenguaje patrio, por no existir ninguna escuela de primera enseñanza en la que se enseñe el español ${ }^{41}$. Esta preocupación por conservar el vínculo de nacionalidad de los emigrantes se hace patente por lo tanto desde comienzos de los años veinte, y se manifiesta especialmente en aquellos que están inmersos en un medio cultural diferente y corren el riesgo, por tanto, de perder la lengua nacional, la principal seña de identidad de la nacionalidad.

Toda esta preocupación por los efectos negativos de la emigración, y en especial por sus consecuencias desnacionalizadoras, desembocó en el Real Decreto Ley de 1924, promulgado ya durante la Dictadura de Primo de Rivera, que venía a desarrollar la ley de 1907 . Ese desarrollo consistía, en primer lugar, en aumentar las trabas a la emigración y en profundizar la acción "tutelar» que le correspondía al Estado. Se acentúa así la actitud paternalista de los poderes públicos hacia el emigrante, al que se considera un menor de edad incapaz de conocer sus auténticas necesidades. Con el objetivo de protegerle se acaba controlando sus movimientos y suplantando su voluntad. Un ejemplo de ello es la Real Orden de marzo de 1929, firmada por E. Aunós, donde se establecía que «en todos los pueblos de España donde existan actualmente Oficinas de Información y despacho de pasajes de emigrantes (de las compañías navieras), se crea con carácter interino, y tan sólo para los efectos de informar verídica y desinteresadamente a quienes pretendan expatriarse, una Junta compuesta por el Alcalde... el Cura Párroco, el Juez Municipal, el Médico titular, el Maestro Nacional y del Secretario del Ayuntamiento.....». Es de imaginar qué tipo de información verídica y desinteresada podían proporcionar las llamadas «fuerzas vivas» de cada localidad a los candidatos a emigrantes.

Pero el Real Decreto Ley de la Dictadura introducía también una novedad importante: establecía la obligación de ejercer una acción «asistencial» hacia los grupos de emigrantes ya instalados en el extranjero, utilizando para ello la red consular y los medios de la Dirección General de Emigración. Esta labor «asistencial» podía desempeñarse en múltiples facetas, por eso es importante cono-

cia en la política cultural española vid. Lorenzo DELGADO y Antonio NiÑO, «Emigración, enseñanza y nacionalidad en las relaciones hispano-francesas», Historia Contemporánea, 10 (1993), pp. 51-101.

41 Despacho del cónsul español en Perpignan, 3 de diciembre de 1928, AGA, Trabajo, $75 / 23084$

Hispania, LXII/2, núm. 211 (2002) 433-482 
cer el punto de vista de los funcionarios encargados de organizarla. En un informe de uno de los inspectores de emigración enviados a Francia se exponía claramente cómo entendía su misión: «Evitar en cuanto sea posible nuestra emigración es el primordial deber que el espíritu de la Ley impone a los encargados de su interpretación y cumplimiento... Puestos a contribución todos los esfuerzos en evitación del mal, y llegado éste fatalmente, hay que proveer a sus consecuencias: tutela al emprender el viaje, asistencia mientras lo realiza, y protección durante su ausencia. Nuestra misión ya es procurar no perderlo para siempre. Hacerlo conservar su amor a España atendiendo a su bienestar, y atraerlo a su repatriación. Toda esta última parte ha de constituir el ministerio de los actuales Patronatos de emigrados; haciendo labor patriótica, de unión y educación social, elevando el nivel cultural y velando por el prestigio y dignidad de la raza» ${ }^{42}$.

Esos Patronatos a los que se refería el inspector fueron otra innovación de la Dictadura, destinada específicamente a cumplir la labor «asistencial» que se había atribuido el Estado ${ }^{43}$. Los Patronatos de emigrantes se crearon específicamente para organizar la atención a los emigrantes en Francia, Argelia y Marruecos, y sustituían a las antiguas Juntas Consulares de Emigración. Estas Juntas se habían encargado casi únicamente de la repatriación de indigentes con cargo a los fondos del llamado Tesoro del Emigrante - un fondo que se nutría de los depósitos de garantía para el regreso abonado por quienes solicitaban un pasaporte de emigrante- Los nuevos Patronatos heredaban esta función, y sumaban además otras nuevas referidas a la atención hospitalaria, la organización de la beneficencia, el mantenimiento de bolsas de trabajo, la creación de escuelas y cursos de adultos, etc. Su creación fue en realidad la respuesta de la administración española a las numerosas denuncias que se publicaban en la prensa sobre la situación de esas colonias de emigrantes ${ }^{44}$. Pero en la sensibilización de la opinión pública tuvo especial repercusión un informe del Cardenal Segura sobre la situación de los emigrantes en Francia y la polémica que desató en la prensa ${ }^{45}$.

El 15 de abril de 1929, tras un viaje de evangelización por el Mediodía de Francia que duró un mes, se publicaba en el boletín eclesiástico del Arzobispado de Toledo una carta pastoral del Cardenal Primado en la que se presentaba

\footnotetext{
. 42 "Memoria ..., Don Joaquín Cabronero». 10 de diciembre de 1929, AGA, Trabajo, 75/23084.

43 Vid. Reales decretos de 31 de agosto y 1 de septiembre de 1929, y. 27 de marzo de 1931.

44 Vid. por ejemplo "Comercio criminal», Informaciones, 4-VIII-1923. «La crisis de trabajo en Francia. El gobierno galo trata de provocar el éxodo de los obreros extranjeros", El Imparcial, 7-III1927. «La situación de los españoles en Francia», La Nación, 23-XII-1927. «Una derrota sin lucha», sobre las naturalizaciones, El Imparcial, 22-I-1928. «Problemas del trabajo. Los españoles en Francia y la política francesa de inmigración», El Imparcial, 22-V-1925.

45 Vid. «Los emigrados españoles en el mediodía de Francia. Un memorial del cardenal Segura a SM el Rey» La Epoca, 8-V-1929. «Memoria del cardenal Segura», El Sol, 9-V-1929. "Los españoles en Francia y én Argelia. A propósito de la memoria del cardenal Segura», ABC, 17-V-1929.
}

Hispania, LXII/2, núm. 211 (2002) 433-482 
«un cuadro desolador» de la miseria moral y material en la que vivía el emigrante español en aquellas tierras. La carta se dirigía a despertar las conciencias de «los españoles que disfrutan tranquilos las delicias de la patria», y aunque su propósito específico no era denunciar a las autoridades francesas, allí se hacían alusiones constantes al «ambiente antirreligioso en minas y fábricas», a la falta de «instrucción doctrinal cristiana», a las trabas para legalizar la situación familiar de las parejas, a las resistencias y dificultades que encontraba la evangelización de los españoles, equiparables, decía el arzobispo, a las que se encuentran «en las mismas Misiones de infieles». El propósito de la carta era solicitar colaboración a favor de las Misiones entre emigrantes, y especialmente la ayuda económica del Estado. Por eso junto a la carta se publicaba un «Memorial sobre los emigrantes españoles del Mediodía francés" (con fecha 17 de mayo de 1928) que el mismo cardenal arzobispo había dirigido al Rey Alfonso XIII. En el memorial se exponían al soberano los logros del viaje, con un mensaje nacional-católico evidente: "han vuelto a renacer... los sentimientos, ya en ellos dormidos, de amor a su fe y a su Patria; y se ha contrarrestado de un modo eficaz la funesta labor de propaganda antisocial con que se les viene soliviantando por los profesionales del mal». A continuación se denunciaban las necesidades de los emigrantes, utilizando para ello un tono dramático: «sus viviendas son bastantes peores que las de los mendigos, morando pésimamente acondicionados en barracones infectos»; sus jornales insuficientes para sostener a la familia; se veían «escenas horribles» de españoles enfermos que no tenían derecho al ingreso en los hospitales franceses ni a los asilos oficiales; abundaban las «uniones ilícitas» por las dificultades que encontraban para contraer el sacramento del matrimonio. Aludía también a los peligros sociales que corrían los emigrantes: la "propaganda de doctrinas disolventes», y en especial de la propaganda comunista «que aterra... Tanto se les infiltra el odio a España y tanto se denigra a la Patria que la mayor parte hasta se avergüenzan de manifestar que son españoles"; peligros en el orden patriótico: la adquisición de la nacionalidad francesa, «a la que se les impulsa por toda clase de medios»; la educación oficial, en la que se prescinde «no sólo de toda idea de Dios y de España», sino también de cualquier noción de lengua española. Por último, el Cardenal se erigía en portavoz de los emigrantes para formular sus peticiones: que los cónsules y vicecónsules sean personas probas y amantes de los españoles; que se subsane el abandono en que los tiene el Estado español, y que «se organice alguna institución protegida por el Estado y que sirva de mutuo auxilio a los españoles»; que se creen Solares españoles o Casas de Misión a cargo del Estado; y que se revise el Tratado con Francia sobre los emigrantes - se refiere al convenio consular de 1868-, que no respondía a las actuales necesidades, con el fin de obtener las mismas ventajas que ya habían obtenido los súbditos italianos.

Este documento fue reproducido por parte de la prensa española provocando un gran escándalo. Casi todos los periódicos opinaron al respecto y hubo alguno, como El Heraldo, que envió a su redactor jefe, Manuel Chaves Nogales, 
a realizar otra encuesta en Narbonne y Carcasonne, obteniendo una impresión muy diferente. Pero a quien más molestó el documento del Cardenal Primado fue a las autoridades francesas. Su primera reacción fue expulsar del país a los dos capuchinos españoles de Carcassonne que habían colaborado con el Cardenal en su viaje de evangelización, por «actividades anti-francesas». A continuación se encargó una encuesta sistemática con el fin de rebatir punto por punto las acusaciones veladas de la carta, y para ello se solicitó al Prefecto de cada Departamento aludido una información minuciosa sobre las verdaderas condiciones de vida de los emigrantes españoles. Los prefectos contestaron la encuesta aportando todo tipo de datos, pero siempre con el propósito evidente de desmentir las acusaciones. Consideraban en general exagerada la forma en que la carta del cardenal había descrito la situación de los españoles, cuando no tendenciosa, injustificada o falsa, pero no dejaban de constatar que en algunos casos se producían ciertamente las condiciones lamentables aludidas, aunque no fueran achacables a la administración francesa.

Confirmaban los prefectos que los españoles llegaban en una situación «vecina a la indigencia», y que vivían en alojamientos poco salubres y estrechos, donde se apiñaban a menudo familias de 8 y 10 miembros en una sola habitación, aunque ello era debido según las autoridades francesas a su deseo de ahorrar lo más posible de sus salarios para mandarlo a España. Si algunos españoles vivían en "barracas infectas" no era porque fueran discriminados, sino por su espíritu de lucro y por su «desprecio de toda higiene». Por otro lado, recibían los mismos salarios que los obreros franceses según su categoría, entre otras cosas porque los sindicatos franceses se encargaban de vigilar que así se hiciera para evitar una competencia desleal en el mercado de trabajo. Lo que sin duda era cierto es que cobraban menos de media porque, al carecer la mayoría de especialización, realizaban las tareas menos agradables y peor remuneradas. Los prefectos reconocían también que según la legislación francesa sobre asistencia médica gratuita, "los extranjeros enfermos sin recursos son asimilados a los franceses siempre que el Gobierno haya establecido un tratado de asistencia recíproca con su nación de origen», y esta condición no se cumplía en el caso de España. Sin embargo, añadían, la beneficencia local les procuraba asistencia hospitalaria por un deber moral, eso sí, según el arbitrio de los alcaldes. También era cierto que no se les admitía en los asilos públicos de ancianos. En cuanto a las uniones libres, en su opinión esta situación no era más frecuente entre los españoles que entre otras nacionalidades. Los costes del registro civil y del certificado de matrimonio eran los mismos que para los franceses, pero los españoles debían además abonar una suma importante en su consulado — juzgada abusiva - por la visa y traducción de sus partidas de nacimiento o de defunción. En cuanto a los peligros morales, los prefectos valoraban muy bien la labor de las sociedades filantrópicas y de socorros mutuos creadas por las colonias porque se encargaban de mejorar su nivel moral y de combatir su aislamiento; pero añadían que los resultados eran limitados porque, como señalaba el prefecto de SaintEtienne, los inmigrantes españoles «son, en su mayor parte, patanes, con una 
educación más que rudimentaria y muy a menudo nula, gente grosera a la que las cosas del espíritu no atraen en absoluto, aunque no parecen sufrir por esta situación ${ }^{46}$. En cuanto a la propaganda comunista sobre los emigrantes españoles, en su opinión no era más intensa que la que recibían los extranjeros de otras nacionalidades o los propios franceses. En todo caso, opinaban los prefectos, los españoles se dejarían ganar más fácilmente por las opiniones anarquistas que profesaban un cierto número de ellos, y no por la propaganda comunista. Y en cuanto a la queja de que a los niños españoles se les daba una educación en la escuela oficial donde aprendían únicamente la lengua francesa y no recibían ninguna idea de Dios ni de España, la respuesta más común era el silencio o una concisa y expresiva anotación: «no merece ser comentada».

A pesar de los desmentidos recibidos del Ministerio francés de Asuntos Exteriores, el Gobierno español se sintió en la obligación de adoptar algún tipo de medida al respecto, y su respuesta fue el encargo a todos los cónsules destinados en Francia de crear Patronatos de emigrantes, bajo la dependencia de la Inspección General de Emigración, encargados de atender todas las necesidades asistenciales que se presentaran. En estos patronatos debían estar representadas todas las asociaciones existentes en cada demarcación y, efectivamente, esas asociaciones recibieron la novedad con entusiasmo, creyendo sin duda que esa sería la vía por la que recibirían el ansiado auxilio económico del Estado español. En los meses siguientes se empezaron a recibir las peticiones de los Patronatos recién constituidos, que constituyen un completo catálogo de las necesidades más sentidas por los colectivos de emigrantes en Francia: organizar bolsas de trabajo; sufragar camas gratuitas en los hospitales para los emigrados enfermos e indigentes; defensa legal en cuestiones laborales y alquileres de vivienda; crear escuelas primarias españolas, donar libros con destino a las sociedades españolas, expedir gratuitamente, en caso de pobreza, los documentos necesarios para contraer matrimonio en el extranjero, etc ${ }^{47}$.

46. «Préfecture de la Loire», Saint-Etienne, 13 de agosto de 1929, AD, Espagne, 133.

47 AGA, Trabajo, 75/23084. Con la proclamación de la Segunda República se introducen algunas peticiones nuevas. Por ejemplo, los representantes de varias Sociedades de Socorros Mutuos de la región de Lyon elevan un escrito al Ministerio de Estado, fechado en Givors el 19 de mayo 1931, donde declaran: «... $1^{\circ}$ - Reconocimiento y adhesión entusiasta a la República Española...2 $2^{\circ}$ - En virtud de la crisis de trabajo que existe en Francia y de las miserias que esta crisis acarrea a los obreros españoles esperamos la pronta repatriación de cuantas familias lo deseen con sus respectivos ajuares sin coste alguno para ellas y una seguridad de trabajo a la llegada a España fuere la región que fuere, $3^{\circ}$ - Teniendo en cuenta que la inmensa mayoría de los prófugos y desertores que se encuentran en Francia tienen formada una familia, solicitamos una amplia amnistía exenta de todo servicio militar para todos los que en este caso se encuentran, $4^{\circ}$ Intervención por parte del Gobierno de la República española acerca del Gobierno francés, a fin de recabar para los súbditos españoles que residan en Francia los mismos derechos que disfrutan los naturales del país, siempre que los mismos tributos rindan, $5^{\circ}$ Estipulación por parte del Gobierno español de una subvención a las Sociedades de Socorros Mutuos...6 $6^{\circ}$ Que el Gobierno intervenga cerca del Cónsul y Canciller de Lyon a fin de que estos guarden el respeto y consideración debidos para sus súbditos (sic)», AGA, Trabajo, 75/23078. 
La actitud de los inspectores mandados por la Dirección General de Emigración fue sorprendente: desaconsejaron la creación de obras de asistencia sanitaria, laboral o jurídica, con el argumento de que el país que les acogía debía ser el encargado de "pechar con sus cargas, empezando por la más elemental de darle carácter internacional al principio de Igualdad y Fraternidad lema de aquella patria de la Libertad» ${ }^{48}$. Proponían, a cambio, concentrar el esfuerzo del Estado únicamente en la atención de sus necesidades escolares y espirituales, porque es "lo que no pueden recibir allí de otra mano", y porque es "lo conveniente a nuestros propios intereses: aquí es sonada la hora de actuación de nuestros organismos tutelares; haciendo hablar español al niño que lo olvidó o al que jamás lo supo; enseñándole a conocer España geográfica e históricamente, aprendiéndole a amarla y cultivando un ciudadano: unir a los mayores en la veneración común de una misma madre: elevar el prestigio de raza al nivel que por derecho propio le corresponde; y, en una palabra, hacer Patria fuera de ella».

Debido a estas recomendaciones y a la falta de asignaciones presupuestarias, los nuevos Patronatos fueron abandonados a su suerte. La falta de subvenciones acabó enseguida con las ilusiones del primer momento y los Patronatos, después de las primeras reuniones, o dejaron de existir, o llevaron una vida lánguida y poco activa. El encargado de negocios francés había advertido sagazmente el fondo de la cuestión: "parece que la intención de este decreto sea, en realidad, no tanto acudir en ayuda de los emigrantes españoles como mantenerles bajo la dependencia de las autoridades reales. En efecto, la mayoría de las medidas previstas necesitarían, para ser efectivamente puestas en vigor, gastos importantes que no son previstos de ningún modo» ${ }^{49}$. En marzo de 1931 se reformó el decreto por el que se regían los Patronatos para limitar su actuación a labores estrictas de promoción cultural y beneficencia. Al reducir sus competencias se hacía menos visible la distancia entre las intenciones y la realidad, pero ello no sirvió para relanzar su actividad. En julio de 1933 sólo se conservaban activos nueve Patronatos ${ }^{50}$, mientras que habían desaparecido en dieciséis ciudades de Francia y del norte de Africa. Pero este fracaso fue compensado en parte por la extraordinaria labor que realizaron los maestros enviados por la República española a partir de 1932, de los que hablaremos más tarde.

48 «Memoria ..., Don Joaquín Cabronero». 10 de diciembre de 1929, AGA, Trabajo, 75/23084.

49 Despacho del encargado de negocios de Francia, San Sebastián, 11 de septiembre de 1929, AD, Espagne, 133.

so Seguían funcionando los de Lyon, Burdeos, Perpignan, Pau, Tarbes, Oloron, Toulouse, Marsella y Cette.

Hispania, LXII/2, núm. 211 (2002) 433-482 


\section{LA ACTITUD FRANCESA ANTE LA EMIGRACIÓN ESPAÑOLA}

Ya hemos dicho que el fenómeno de la emigración española en Francia surge cuando aparece una ingente oferta de empleo en sectores tradicionales como el agrícola, desertado por los trabajadores autóctonos que estaban avanzando en el proceso de urbanización, o en sectores como el industrial y el minero, coyunturalmente abandonados por una circunstancia excepcional como fue la Primera Guerra Mundial. La necesidad imperiosa de mano de obra extranjera hizo que la administración francesa facilitara su llegada masiva: para ello no tenía más que permitir a los trabajadores entrar en el país sin pasaporte, aprovechando la ausencia de control en la frontera terrestre española, y dirigirlos a las oficinas de inmigración donde les otorgaban una Carta de Identidad y de Circulación - con la localidad a donde debían dirigirse - y un contrato de trabajo. En esos años las únicas preocupaciones de los poderes públicos eran cómo surtir convenientemente las necesidades del mercado de trabajo, y cómo organizar esa mano de obra de la forma más eficaz. Pero a lo largo de los años veinte y treinta se produjo una evolución muy significativa en la sociedad francesa: si al principio las preocupaciones se referían exclusivamente al comportamiento de la oferta de empleo, o a las características de la mano de obra que accedía al país, la cuestión se desplazó progresivamente hacia aspectos de orden público y de seguridad, para acabar dominada por consideraciones de tipo político y cultural. Lo que hasta entonces se había considerado una necesidad se fue convirtiendo poco a poco en una amenaza. Y lo más importante es que este significativo desplazamiento, desde un análisis estrictamente económico del fenómeno a otro dominado por los efectos de la presencia de extranjeros sobre la identidad colectiva, no se produjo cuando la inmigración adquirió un carácter masivo, sino cuando cambió la percepción que de ella se tenía.

En 1924 las autoridades francesas ya consideraban que el flujo de gran número de trabajadores extranjeros creaba una situación «inquietante» desde el punto de vista de la salud pública. Los problemas de la inmigración dejaron de ser sólo problemas laborales para abarcar también los aspectos sanitarios y las condiciones de vida de una mano de obra especialmente desprotegida. Aumentaban las quejas por los gastos que generaban en los hospitales y hospicios municipales ya que, aunque no se reconocía a los extranjeros el derecho a la atención gratuita como indigentes, algunos alcaldes accedían a ello por razones simplemente humanitarias. «Un español — decía un inspector en viaje de misión por Francia - no es para ellos un ser que contribuye al desenvolvimiento económico de su país, que va a producirles riqueza que ellos disfrutan, que les permite dedicarse a faenas menos penosas y más productivas dejando gravitar sobre los hombros de los extranjeros las más odiosas y menos recompensadas; el español es para ellos una peste que llena los hospitales» ${ }^{51}$. El principio de la

51 «Memoria ... Fernández Flórez», 11 de diciembre 1929, AGA, Trabajo, 75/23084.

Hispania, LXII/2, núm. 211 (2002) 433-482 
igualdad republicana, que sí se aplicaba en las escuelas por la necesidad de asimilar a la segunda generación de inmigrantes ${ }^{52}$, no regía en las instituciones asistenciales, donde se imponía el principio de la prioridad nacional. Por otro lado, tratándose de sectores populares y de mano de obra sin cualificar en una situación de precariedad extrema, era lógico para las autoridades francesas deducir que el problema podía convertirse también en una amenaza desde el punto de vista del orden público. Se tendía a equiparar inmigración con peligrosidad social, especialmente por las supuestas actividades comunistas y anarquistas de los españoles. Según una comisión interministerial creada para estudiar la cuestión, la concentración de gran número de trabajadores expatriados que llevaban en su mayoría una existencia miserable y a menudo sin trabajo, «crea un medio particularmente favorable a la propagación de doctrinas comunistas y revolucionarias" ${ }^{53}$. Ya entonces se propusieron diversas medidas preventivas que reflejan claramente la mezcla de necesidad y temor con la que se afrontaba la cuestión. La primera propuesta de la comisión era ejercer un atento control de los inmigrantes y expulsar a los que fueran considerados indeseables o sospechosos. Se recomendaba, además, dispersarlos por el conjunto del territorio - ya que expulsarlos en masa a sus países de origen se reconocía tarea imposible - y fraccionar los grupos de trabajadores extranjeros utilizando para ello las oficinas de colocación. Esta era una medida de policía, pero también una forma de dar a la mano de obra extranjera «una utilización racional, adaptada a las diversas necesidades de la economía nacional». El peligro, en el caso de los italianos, era la acción de los fascios en el extranjero y la política de captación ideológica del Gobierno fascista. En el caso español dominaba sobre todo la imagen de peligrosos revolucionarios, asociada al estereotipo del emigrante miserable, analfabeto y de origen rural. La comisión proponía por ello organizar una propaganda metódica en su lengua y a través de la prensa sindical para preservarles de la agitación comunista. Junto a ello, consideraba importante mejorar la suerte y las condiciones de existencia material de estos trabajadores, creando para ellos obras de asistencia, y exigiendo a los empleadores que hicieran el esfuerzo necesario para ofrecer a sus obreros un alojamiento suficiente. Por último, se debía facilitar el reagrupamiento familiar y organizar la instrucción de sus hijos en escuelas francesas «donde se les enseñaría nuestra lengua y donde recibirían una educación destinada a facilitar posteriormente su asimilación por nuestra población $»^{54}$.

\footnotetext{
\$2 Y esto también sería discutido por los partidos de la derecha desde 1930. Vid. Olivier LOUBES, «L'école et les étrangers: assimilation et exclusion», en Pierre MILZA y Denis PESCHANSKI (Dirs.), Exils et migrations. Italiens et espagnols en France, 1938-1946, Paris, L'Harmattan, 1994, p. 264.

53 "Note au sujet du Régime...», 22 noviembre 1924, AD, Espagne 272. En este nota se diseña un programa de actuación conjuntamente entre el Ministerio del Interior, el de Asuntos Exteriores y el de Justicia.

54 «Note au sujet du Régime....», 22 noviembre 1924, AD, Espagne 272.
} 
Se trataba de una política articulada que reflejaba bien esa creciente prevención hacia los inmigrantes como un foco potencial de alteraciones. Pero no eran sólo las autoridades: también los sindicatos franceses comenzaron a exigir un mayor control sobre los trabajadores extranjeros que, desde su punto de vista y sobre todo en el sector industrial, suponían una competencia indeseable para la mano de obra nacional. Aparecieron así las primeras medidas para dar prioridad en el mercado laboral a los trabajadores nacionales. Desde 1924 los prefectos ya sólo concedían permisos de residencia en el país a los trabajadores que hubieran obtenido un contrato de trabajo controlado por la Oficina departamental de Mano de Obra Extranjera y visado por el Ministerio de Trabajo, y estos organismos, a su vez, no daban su visto bueno mientras existieran obreros franceses disponibles en el mismo ramo. Con los trabajadores agrícolas, sin embargo, se era más permisivo ya que se suponía que no constituían una competencia para la mano de obra local.

Así, la actitud de las autoridades francesas ante la emigración se hacía cada vez más paradójica según avanzaba la década de los veinte: por un lado se reconocía la absoluta necesidad de la mano de obra extranjera, pero por otro se agudizaba el recelo siempre latente contra el extranjero. Aumentaban las prevenciones ante el aumento de la inmigración, pero se seguía propugnando la asimilación forzada de esa población extraña. La población autóctona tendía también a identificar de forma creciente a esos emigrantes con «gente problemática»: al fin y al cabo, eran trabajadores que vivían en muy precarias condiciones de vida, lo que creaba las condiciones para que se les encuadrara en la categoría de clases inferiores. Además, el inmigrante reciente era un individuo que no participaba en las redes culturales, políticas y relacionales del país de acogida. Las propias administraciones locales no consideraban de su responsabilidad la atención de esos individuos que estaban excluidos del campo social. Surgían así las condiciones para que se produjera el rechazo y una creciente hostilidad. Esa convivencia entre la necesidad económica de la aportación de mano de obra extranjera, y una disposición crecientemente hostil, dio como resultado una oscilación a veces brusca de políticas inmigratorias favorables o adversas, según la coyuntura.

Francia, de todas maneras, fue el único país europeo que arbitró desde muy pronto medidas para asentar definitivamente a la población inmigrante. Esta actitud contrasta con la que adoptarían el resto de los países europeos cuando, a partir de los años cincuenta, recibieron contingentes laborales del extranjero para acompañar su crecimiento económico. En éstos primó el principio de temporalidad: la legislación no favorecía el asentamiento sino la transitoriedad. La legislación alemana y helvética, por ejemplo, fueron muy firmes en su objetivo de desmotivar el asentamiento definitivo y dificultar el acceso a la nacionalidad. Para comprender las políticas francesas de integración del inmigrante, algo muy característico de ese país, hay que tener en cuenta que desde muy pronto se consideró la inmigración como un remedio inevitable al declive de su natalidad, y 
una manera de poblar el país. A principios del siglo XX Francia era el único país de Europa que declinaba demográficamente y que atraía a un gran número de inmigrantes italianos, polacos y españoles. La opinión francesa era muy consciente de que el país arrastraba un problema de bajo crecimiento demográfico, agravado por las pérdidas de población de la Guerra Europea, que comprometía la misma renovación generacional. Francia, se decía, tenía necesidad de sangre nueva y la integración de los emigrantes de la Europa mediterránea era considerada la única solución posible. Fue la conciencia de esa crisis demográfica, que se remontaba a mediados del siglo XIX, y el deseo de solucionarla la que impulsó una política de rápida asimilación del trabajador extranjero. Esa política se apoyó, a su vez, en dos pilares fundamentales: las facilidades otorgadas para la naturalización de los extranjeros residentes en el país, y su integración cultural para adaptarlos al molde de valores de la nacionalidad francesa. Cuando llegaron masivamente los españoles, esa política ya estaba suficientemente desarrollada y era aplicada sistemáticamente a todos los extranjeros.

\section{LAS POLÍTICAS DE NACIONALIDAD}

Inicialmente, el fenómeno de la inmigración se contemplaba exclusivamente como una cuestión de derechos y deberes que de ningún modo prejuzgaba la identidad de los sujetos. Hasta finales del siglo XIX el extranjero podía elegir entre asimilarse o conservar su especificidad, con un status civil particular, sin que el Estado favoreciera su decisión en uno u otro sentido. Esta fue, por otro lado, la política aplicada a los inmigrantes franceses instalados en España: técnicos y cuadros profesionales de alto nivel sociocultural en general, para los que no se planteaban las cuestiones de la pérdida de nacionalidad o del peligro de asimilación.

En Francia, la crisis demográfica hizo que cambiara esa forma tradicional de enfocar la cuestión en favor de otra perspectiva que contemplaba las aportaciones de la población inmigrante como una forma de compensar sus bajos índices de natalidad. Eso significaba forzar la integración de los inmigrantes extranjeros, y uno de los principales instrumentos utilizados por el Estado para lograrlo fue el derecho de nacionalidad. Como el vínculo de nacionalidad pertenece al derecho público interno, éste podía ser modificado según las necesidades internas sin tener en cuenta sus consecuencias internacionales. La clave de esta política fue la reforma del Código Civil francés de 1889, que modificaba la legislación sobre nacionalidad haciendo mucho más fácil su adquisición por los extranjeros residentes en el país. La ley de 26 de junio de 1889 tenía como objetivo precisamente hacer de la naturalización un modo normal de incrementar la población francesa. Uno de los procedimientos consistió en la práctica supresión de la situación intermedia que constituía «l'admission à domicile», que había permitido hasta entonces que los extranjeros residentes dis- 
frutaran de casi las mismas ventajas que los nacionales sin soportar sus cargas. Pero la mayor novedad de la nueva ley era que establecía el principio del ius soli, según el cual se consideraba francés a todo hijo de extranjero nacido en Francia que residiera en el país a la mayoría de edad, a menos que renunciara expresamente a la nacionalidad francesa. Del mismo modo, se consideraba francés a toda persona nacida en Francia de un extranjero que, a su vez, hubiera nacido también en dicho país: en este último caso la nacionalización era automática, al margen totalmente de la voluntad del individuo. Por otra parte, también se podía acceder a la nacionalidad por residencia prolongada y por matrimonio mixto, es decir, por amalgamación. Se abrían así tres vías diferentes por las que se avanzaba rápidamente en el proceso de naturalización de los emigrantes. Esas facilidades, combinadas con una sanción legal a quien mantuviera la condición de extranjero - privación de derechos sociales y políticos, amenaza de expulsión, etc.- constituían un poderoso aliciente y una manera eficaz de fomentar las solicitudes de naturalización.

Esa legislación fue reformada de nuevo en 1927 para dar aún más facilidades a la naturalización de los extranjeros. Hasta entonces se exigía, por regla general, que el interesado pudiera justificar una estancia en Francia de al menos diez años para poder obtener una naturalización por residencia, lo que se consideraba necesario para asegurar que el extranjero hubiera sido efectivamente asimilado. La ley de 10 de agosto de 1927 limitaba ese plazo a tres años en la mayor parte de los casos y concedía, además, nuevas facilidades en el caso de matrimonios mixtos.

El efecto de este último cambio legislativo parece haber sido inmediato. Aunque no hemos encontrado estadísticas seguras, diversos testimonios de fuentes españolas advierten del considerable aumento de naturalizaciones que se produjo ese mismo año. Según el cónsul en Hendaya, «desde que se promulgó la Ley de Nacionalizaciones de 10 de agosto de 1927, inspirada de un marcado carácter de atracción, facilitando los plazos y las formalidades, las nacionalizaciones pasaron de 1.500 al año, a la cifra enorme de 84.098 en los cinco meses restantes. De esta cifra, según los datos del Ministerio de Gracia y Justicia francés, la mitad de los obreros nacionalizados son italianos y españoles. Según los datos que he podido recabar personalmente, los españoles que en estos cinco meses han perdido su nacionalidad son 18.603 , cifra enorme... de un total de 195.000 el año anterior»"s. Siguiendo con sus cálculos, el cónsul aseguraba que en diez años no habría colonias de españoles en Francia si se seguía a ese ritmo, absorbidos «por esta ley de osmosis social», y concluía: "por falta de asistencia y convencidos de su inferioridad, nuestros emigrantes se dejan ganar por la nacionalidad francesa, que les asegura la estabilidad e igualdad que inútilmente buscan ahora. Esta es una amenaza evidente». Según una noticia aparecida en El Imparcial de 22 de enero 1928, y que remitía a fuentes francesas, 38.000 personas, entre españoles e italianos, se habían naturalizado fran-

ss Informe del cónsul de España en Hendaya, 1 de abril de 1928, AGA, Trabajo, 75/23093. 
ceses en 1927, sin poder saber cuántos exactamente eran españoles. Aun suponiendo que la mitad fueran españoles, añadía el artículo, «representan un capital enorme; son el efectivo de una división en pie de guerra; el vecindario de una urbe de segundo orden, y la capitalización de sus cédulas de vecindad, jornales o sueldos, documentos sellados e importe de contribuciones, suma casi tanto como el superávit del último presupuesto; han trabajado en balde el ministro de Hacienda y los respectivos padres de los nuevos ciudadanos franceses. Todo se lo ha llevado Francia». El embajador en París, por su parte, estimaba que con sólo cinco meses de efectividad, «las bajas producidas en nuestra nacionalidad (por la ley de 10 de agosto de 1927), pasaron de 1.500 a la exagerada cifra de $18.603 »^{56}$. Las cifras variaban, pero la preocupación era la misma. A todos los informantes les parecía una sangría gravísima que había que evitar por todos los medios, aunque no coincidieran en el análisis de las causas ni de las soluciones.

Las cifras que aportan las fuentes francesas son igualmente fragmentarias, pero sirven para confirmar la importancia del fenómeno. En 1928, según el prefecto de Nîmes, 28 jefes de familia y sus 43 hijos se habían naturalizado en esa localidad. En Tarbes, sobre 124 naturalizados en los dos últimos años, 102 era españoles. A pesar de no llevar un registro de las naturalizaciones que se producían, las autoridades del país mostraban una evidente satisfacción cuando se referían a ese fenómeno. Negaban, para empezar, que se forzara de ninguna manera la voluntad de las personas que solicitaban la naturalización. Según el prefecto de Hautes-Pyrénées, «no hay necesidad de ejercer ninguna presión en este sentido. Los emigrados españoles, que no pudieron encontrar en su casa medios suficientes de existencia, han saboreado la alegría de vivir desde la llegada a nuestro país. Ninguna influencia ha sido necesaria para hacerles amar a Francia, el país de todas las libertades ${ }^{57}$. El comisario especial de Marsella afirmaba, a su vez, que «los españoles se adaptan muy bien a la existencia que llevan en nuestro territorio. Aprecian muy especialmente los beneficios del régimen republicano y son ellos mismos los que solicitan la cualidad de franceses que les asegura, en su vejez, todas las ventajas de nuestras leyes asistenciales» ${ }^{8}$. El prefecto de Carcassonne opinaba por su parte que «si desde hace algunos años parecen más numerosos los que solicitan la nacionalidad francesa, la razón, que no ocultan, es que han adquirido en suelo francés mejores condiciones de vida, desahogo y confort». Y el de Saint-Etienne: «aquellos que quieren hacerse franceses son empujados a ello por el interés, con el fin de beneficiarse, ellos y su numerosa familia, de las diversas obras de beneficencia o de asistencia, así como de las leyes sociales existentes» ${ }^{59}$.

\footnotetext{
s6 Despacho del embajador en París de 31 de agosto de 1928, AGA, Trabajo, 75/23084.

57 "Préfecture des Hautes-Pyrénées», Tarbes, 26 de julio de 1929, AD, Espagne 133.

58 «Préfecture des Bouches du Rhône», Marsella, 21 de agosto de 1929, AD, Espagne, 133.

59 «Préfecture de la Loire», Saint-Etienne, 13 de agosto de 1929, AD, Espagne, 133.
} 
Las explicaciones manejadas son muy distintas cuando los informantes son las autoridades consulares o los funcionarios españoles. En sus análisis no aparecen alusiones a la bondad del régimen republicano, a las libertades que allí se disfrutan o a la «joie de vivre» en la encantadora Francia. Sí hay coincidencia en apreciar el efecto de una legislación social más avanzada, como cuando un inspector español de emigración opinaba que la razón por la que muchos emigrados pedían la naturalización era que se sentían estimulados por las atenciones sociales «copiosas» de las que se benefician los naturales del país ${ }^{60}$. Pero las fuentes españolas dan otras razones para explicar las causas del cambio de nacionalidad. En una enumeración prolija, un inspector afirmaba que: «mucha culpa de esas naturalizaciones que son alarmantes (en Montpellier se registran 550 en lo que va de año) la tiene esa constante labor de desprestigio que realizamos constantemente dentro de nuestra propia casa. Se piensa que cualquier país ofrece mayores ventajas que España, tenemos desconfianza de nuestro propio valor y todo obrero cree que en cualquier parte del mundo ha de vivir mejor. (...) Otro enemigo del patriotismo son las uniones mixtas en que la mujer es extranjera, que nunca llega a saber español y que es la encargada de la educación de sus hijos. En esas familias el lenguaje familiar será el de la madre que inculcará a sus hijos su indiferencia hacia las cosas de España, cuando no la consecuencia del odio que calladamente siente hacia el marido a quien no ha llegado a comprender. Pero lo que más debilita nuestro contingente es el servicio militar, la indiferencia para hacerse inscribir en los Consulados. El hijo no conoce España y hasta llega a creerse francés por haber nacido en aquella tierra; el padre piensa que le ahorrará muchos sinsabores con solo dejar hacer y cuando llega el día de la elección nadie se preocupa de ello» ${ }^{61}$.

La falta de patriotismo es la causa más citada por esos inspectores que veían en la emigración una forma de deserción, y en la naturalización una auténtica traición a la patria. Por eso mismo, la asistencia cultural y educativa era la más valorada pues debía servir para atacar directamente el mal: la ausencia de orgullo y de afecto por la nación de origen ${ }^{62}$. Pero en esos informes también hayamos citadas algunas de las presiones que de forma sistemática organizaba el país de inmigración: «En el caso de Francia, esta política es de franca atracción a la naturalización del elemento extranjero. A ello tienden todas las medidas y todas las dificultades que hacen sus funcionarios. Se empieza por no reconocer a los expatriados derecho a la beneficencia municipal y por negarles una cama en los hospitales, por retirarles las pensiones de accidentes del trabajo si

60 «Memoria ..., Don Joaquín Cabronero». 10 de diciembre de 1929, AGA, Trabajo, 75/23084.

61 «Memoria ... Fernández Flórez». 11 de diciembre 1929, AGA, Trabajo, 75/23084.

62 Un estudio más detenido del sentimiento nacional entre el colectivo de emigrantes permitiría contrastar la hipótesis según la cual una de las características del desarrollo de la sociedad española contemporánea es el fracaso del esfuerzo de nacionalización del conjunto de la población, y en especial de sus clases populares. Ese débil sentimiento nacional, a su vez, se ha relacionado tradicionalmente con el poco desarrollo de la educación popular y de la cultura nacional. 
no viven en Francia y se termina por darles todo género de facilidades para la naturalización que les conduce a disfrutar de éstos y de otros beneficios. Los funcionarios ponen toda clase de trabas a los extranjeros, como sucedió en Lyon con la política que exigía una crecida suma por el visado de la tarjeta de identidad y pretendiendo la existencia de mucho trabajo se hace volver a los interesados 10 o 15 días después de transcurrido el plazo señalado para estos visados con el objeto de poder multarles» ${ }^{63}$. No poseer la nacionalidad significaba, en primer lugar, ser excluido de la ciudadanía, estar desprovisto de ciertos derechos políticos como el de la elegibilidad y el sufragio, vivir bajo la amenaza de expulsión, y ver sometidas a estrecha supervisión sus actividades sindicales y políticas. Pero también se perdían derechos sociales: el derecho a la asistencia gratuita en caso de indigencia, por ejemplo. La naturalización era una solución a todos estos problemas, y además facilitaba al inmigrante participar en el tejido sociocultural del país de acogida y beneficiarse del proceso de movilidad social. Había pues un conflicto planteado entre los dos Estados en el que no cabían posturas intermedias. Sólo se podía luchar, como decía un inspector español, "para contrarrestar la política de naturalización» seguida por Francia, con medidas que incentivaran la conservación de la nacionalidad española, y para ello se le ocurrían las siguientes:

" $1^{\mathrm{a}}$ - Los hijos de españoles nacidos en Francia que sin interrupción residieran en ella hasta el momento de la elección de la nacionalidad podrán acogerse al Real Decreto que regula el servicio militar de los emigrados en América.

$2^{\mathrm{a}}$ - La creación de una Casa de Maternidad en un pueblo próximo a la frontera y costear el viaje a las madres a fin de que nazcan españoles los hijos de los emigrados.

Fuera de ello no hay otra solución, a mi juicio, que laborar dentro de España para arrancar a la emigración el mayor número de hombres. (...) En fin, que todas esas beneficiosas instituciones que queremos fundarles en el extranjero funcionen dentro de casa. Y gastemos nuestro dinero también dentro de la Nación para que dentro de ella se multiplique» ${ }^{64}$. De nuevo aparece la preocupación por el despilfarro del presupuesto nacional en atender a una población expatriada de la que se debía ocupar, según el inspector, el país que se beneficiaba de su trabajo.

Al lado de esta política sistemática y organizada para incentivar la inclusión del inmigrante en la sociedad adoptiva, actuaban otros factores que, de forma natural y espontánea, minaban los vínculos con la sociedad de origen. En primer lugar estaba la distancia, en el tiempo y en el espacio, con la que el emigrante contemplaba la tierra que había dejado, lo que acababa reflejándose también en su comportamiento. Desarraigo, nostalgia, desesperación son algunas de las secuelas que produce la distancia. En algunos casos, esa distancia podía intensi-

63 «Memoria ..., por Fernández Flórez». 11 de diciembre 1929, AGA, Trabajo, 5/23084.

64 Ibídem, 11 de diciembre 1929, AGA, Trabajo, 75/23084. 
ficar su identidad nacional y el sentimiento de unas profundas raíces históricas; en otros, podía predominar la vivencia de la discontinuidad y de la ruptura, imponiéndose las nuevas solidaridades del momento. Todo dependía, creemos, de los círculos íntimos y de los pequeños sistemas de redes en los que se movía el emigrante, que acababan determinando su identidad personal y por lo tanto su identificación nacional. Por eso resulta muy aguda la observación del embajador en París cuando señalaba que: «el medio más eficaz de contrarrestar esta sangría es, sin duda alguna, la creación de centros de cohesión y mutualismo donde nuestros obreros encuentren calor y ayuda no dejándose ganar por ninguna otra nacionalidad» ${ }^{65}$.

Desde el lado francés las cosas se veían de forma muy distinta. En un informe de la policía de 1927 se aseguraba que los españoles «no tienen una forma de vida diferente de la nuestra; adoptan sin dificultad nuestros usos y costumbres. Pero son en general refractarios a la naturalización. Algunos catalanes, después de haber residido en el Midi, contraen matrimonio con francesas y solicitan nuestra nacionalidad; pero normalmente esperan para ello haber pasado la edad de las obligaciones militares. ${ }^{66}$. El prefecto de Montpellier desmiente que la asimilación obedeciera a falta de patriotismo o estuviera estimulada por el deseo de librarse del prejuicio de la infravaloración del extranjero: «los españoles hacen alarde de apego a su patria con un sentimiento de legítimo orgullo, hablando su lengua en las reuniones, en sus sociedades y exteriorizando ostensiblemente ese apego mediante la exhibición de la bandera española en las celebraciones y en los duelos, no solo de su grupo, sino también de las localidades que habitan y de Francia» ${ }^{67}$. Sólo en Argelia el ritmo de naturalizaciones parecía satisfactorio a las autoridades: en 1926, antes de la reforma legislativa, se naturalizaron 4.328 españoles. Parece ser cierto que las declaraciones de niños menores de edad y los matrimonios mixtos entre españoles y franceses eran menos frecuentes que los que protagonizaba la colonia italiana, lo que indica una menor disponibilidad relativa a la naturalización y a la amalgamación ${ }^{68}$. Según Laborie, la emigración española en el sur de Francia se caracterizaba precisamente, frente a la italiana, por «los marcados particularismos y por su voluntad de reafirmarlos como una dimensión esencial de su identidad, tanto antes como después de los acontecimientos de los años treinta. Unos rasgos de personalidad que se traducen no tanto en la permanencia de unos modos de vida inalterados como en la expresión de un orgullo nacional muy firme y en la voluntad o el deseo, siempre proclamado, de volver lo más

65 Despacho del embajador en París de 31 de agosto de 1928, AGA, Trabajo, 75/23084.

66 «Les emigrés espagnols en France», informe confidencial del Bureau du Contrôle des étrangers, 15 de febrero de 1927, AD, Espagne, 133

67 «Le Préfet de l'Hérault», Montpellier, 5 de julio de 1929, AD, Espagne, 133.

68 MILzA, Pierre y PesChANSKI, Denis (dirs.), Exils et migrations. Italiens et Espagnols en France, 1938-1946, Paris, Eds. l'Harmattan, 1994, p. 37. 
pronto posible a su país» ${ }^{69}$. Ante apreciaciones tan distintas: resistencia a la naturalización por exceso de orgullo nacional para unos, flaqueza ante las presiones a favor de la asimilación por la debilidad de su patriotismo para otros, sólo cabe concluir que tanto unos como otros hacían un diagnóstico inspirado inevitablemente por sus expectativas y sus deseos. A los informadores no les era indiferente el fenómeno de las naturalizaciones, y donde unos veían una sangría en forma de torrente, otros advertían sólo un goteo que apenas garantizaba el éxito de la transfusión.

Para evitar los efectos perversos de la metáfora sanguínea - unos en busca de sangre nueva que revitalizara su organismo, otros intentando taponar la hemorragia que debilitaba el suyo- algunos idearon una solución que permitía compartir los recursos humanos. Pero la solución de la doble nacionalidad que, como vimos, ya fue estudiada por el Gobierno de Primo de Rivera, ni siquiera fue planteada para el caso de la emigración a Francia. Desde luego, en ningún caso llegó a ser considerada por el país receptor de emigrantes como un mecanismo posible y válido de integración. En Francia no se concebía que un individuo pudiera tener dos patrias y, en todo caso, la doble nacionalidad se contemplaba como una fuente de conflictos y una limitación intolerable a la autoridad del Estado sobre los sujetos. Para un país emisor de emigrantes como España, sin embargo, la doble nacionalidad podía ser el único medio de conservar los vínculos con sus ciudadanos expatriados, y así lo entendió la República Española al regularla en tratados internacionales con Estados «de particular vinculación histórico-cultural», como eran las Repúblicas Hispanoamericanas. Mucho menos se pudo plantear entonces la disociación de la condición de nacionalidad y ciudadanía, nociones que permanecían fundidas desde la Revolución Francesa ${ }^{70}$, y que sólo recientemente han sido separadas de nuevo en el Tratado de la Unión Europea. En este documento se ha introducido la noción de ciudadanía europea, con su derecho a la participación política, que permite actualmente en la mayoría de los Estados de la Unión Europea ejercer el derecho de sufragio activo sin la condición de poseer la nacionalidad.

En todo caso, la coyuntura de mediados de los años veinte es especialmente interesante porque en ella coincide la modificación del código francés de nacionalidad, destinada a facilitar la naturalización de extranjeros, con la orientación crecientemente nacionalista de la dictadura de Primo de Rivera que se manifiesta en una nueva legislación orientada a proteger a los emigrantes y mayor intervención del Estado español en apoyo de sus nacionales expatriados.

69 LABORIE, Pierre, «Les espagnoles et les italiens dans l'imaginaire social», en Pierre MILZA y Denis PESCHANSKI (dirs.), Exils et migrations. op. cit. p. 284.

70 Vid. RODRÍGUEZ-DRINCOURT, Juan, «La nacionalidad como vía de integración de los inmigrantes extranjeros», Revista de Estudios Políticos, 103 (enero-marzo 1999), pp. 171-185.

Hispania, LXII/2, núm. 211 (2002) 433-482 


\section{EL PAPEL DE LA ESCUELA}

La naturalización fue la columna vertebral de la solución jurídica a los problemas de inmigración, pero no era el único instrumento de integración. Al fin y al cabo, la nacionalidad sólo establecía vínculos jurídicos y políticos entre un individuo y un Estado; no creaba por sí misma lazos de afecto y lealtad entre el individuo y la comunidad. Para eso la asimilación política debía ser acompañada de una asimilación cultural.

Es sabido que Francia es un país que se piensa como una nación «a la francesa", constituida por ciudadanos formados en la escuela "republicana» que suscriben voluntariamente un contrato de adhesión a la nación ${ }^{71}$. La definición de la nacionalidad francesa se basa por lo tanto más en la asimilación voluntaria que en la similitud. «No se es francés solamente por tener sangre francesa; se es francés - decía el primer ministro Alain Juppé en un artículo recientepor voluntad, por adhesión: por amor a una tierra, a una historia, a una cultura, a una comunidad. Ése es el sentido de la nacionalidad francesa» ${ }^{72}$. Efectivamente, tradicionalmente la sangre no juega un papel determinante en la definición de su nacionalidad, ni la etnia ni la confesión, pero tampoco es cierto que sólo importen los aspectos vinculados a la ciudadanía política. La nacionalidad está ligada también a la pertenencia cultural, al uso de una lengua y a ciertos valores, y no sólo a la aceptación de unas normas que hacen iguales a los individuos en el espacio público. De hecho, lo que caracteriza la tradición republicana francesa es que para acceder a ese «nosotros», a sus códigos y a los derechos y deberes que corresponden a todos los ciudadanos, hay que asumir ciertos valores colectivos, renunciando si es preciso a la singularidad en el espacio privado: eso significa precisamente asimilarse.

Es común afirmar que, por medio de la educación, el Estado interviene normalmente en la construcción cultural de los ciudadanos, inculcándoles la fidelidad a una concepción de la nación. En Francia, además, la escuela era percibida como un pilar fundamental de la síntesis nacional republicana, la encargada de crear una memoria compartida y de uniformizar las prácticas culturales. El papel nacionalizador que había desempeñado tradicionalmente la escuela republicana respecto a la propia población francesa, se hacía más importante si cabe en el caso de los extranjeros pues se trataba de asegurar la lealtad de individuos que poseían una identidad nacional anterior. La inmersión de

71 Vid. LOUBES, Olivier, «L'école et les étrangers: assimilation et exclusion», en MILA, Pierre y PESCHANSKI, Denis (dirs.), Exils et migrations. op. cit., pp. 259-271.

72 Vid. Le Monde y EL PAIS, 27-II-1997. Ese artículo se publicó con motivo del debate suscitado por el proyecto de ley de extranjería, conocido como proyecto Debré. Alain Juppé calificaba a la nación francesa como aquella "constituída por hombres y mujeres que han elegido vivir juntos». Allí mismo calificaba la inmigración como «un auténtico problema que no tenemos derecho a ignorar», y que se soluciona no con «el discurso del odio y exclusión», sino con «la integración de todos los que quieren compartir nuestros valores, empezando por la laicidad republicana».

Hispania, LXII/2, núm. 211 (2002) 433-482 
los hijos de inmigrantes en la escuela primaria, laica, gratuita y obligatoria, permitía acompañar la integración jurídica con «una integración del espíritu y del alma», por un proceso de identificación mental, al mismo tiempo que se convertía en un vector fundamental de asimilación de los inmigrantes adultos al transformar a los niños en edad escolar en los mejores agentes de la cultura francesa ante sus padres y en sus propios hogares. Se suponía además que este método permitía alcanzar una asimilación sin dolor pues, aunque para ello era necesario diluir la cultura original que impregnaba a los sujetos para hacerlos perder su especificidad identitaria, esta operación se hacía mediante una acción lenta aunque profunda. La asimilación comenzaba pues con la aculturación, es decir, con la inculcación de los valores y normas propios de la población nativa. La aculturación preparaba así el camino para la asunción de una nueva identidad nacional. En este proceso la escuela era el instrumento privilegiado porque garantizaba el aprendizaje cultural y la inculcación de una memoria y unos valores compartidos por todos los ciudadanos. De ahí el carácter estratégico que tenía la cuestión de la escolarización de los hijos de los inmigrantes. Lo que se perseguía en su caso no era proporcionarles una instrucción escolar, ni una cualificación profesional, ni siquiera una formación como futuros ciudadanos; el objetivo fundamental era forzar su asimilación, es decir, su identificación con la nación francesa, con su historia, con su cultura y con su autopercepción como colectivo ${ }^{73}$.

Estas funciones las cumplió normalmente la escuela francesa durante el periodo de entreguerras. El ideal laico e igualitario de la escuela republicana no reconocía las diferentes identidades, anulaba las diferencias culturales, lingüísticas y religiosas, pero los alumnos y sus padres se prestaban con facilidad a ello por cuanto sabían que era la única oportunidad que tenían de superar el handicap lingüístico y de ascender algún escalón en la escala social ${ }^{74}$. Los emigrantes tendían a hacer un gran esfuerzo de inversión en «capital humano», pero no en ellos mismos, sino en sus hijos, lo que a veces justificaba por sí mismo el esfuerzo de la emigración.

Esa función de asimilación se haría aún más relevante en la medida en que las autoridades francesas eran conscientes de «los esfuerzos realizados por los gobiernos extranjeros para impedir la desnacionalización de sus emigrantes» ${ }^{75}$. El Gobierno francés se propuso expresamente contrarrestar esos esfuerzos, evitar el agrupamiento de los emigrantes, dificultar la actuación de sus cónsules e impedir que se dotaran de escuelas propias. El Gobernador General de Argelia lo decía muy crudamente en 1926: «Francia, obligada a acoger sobre su terri-

73 Vid. el informe de síntesis que acompaña al recuento de extranjeros en las escuelas francesas realizado en 1930, citado por LOUBES, Olivier, "L'école et les étrangers : assimilation et exclusion», en MIIZA, Pierre y PESCHANSKI, Denis (dirs.), Exils et migrations. op. cit., p. 263.

74 AMAR, Marianne y MILZA, Pierre, L'immigration en France au XXe siècle, Paris, A. Colin, 1990, p. 108-109.

75 Nota del Ministro francés de la Educación Nacional, Jean Zay, de 13 de noviembre 1938, citada por Olivier LOUBES, art. cit., p. 265.

Hispania, LXII/2, núm. 211 (2002) 433-482 
torio una numerosa colonia extranjera por la insuficiencia de su natalidad, no puede albergar la esperanza de asimilar a estos extranjeros mas que separándoles lo más rápidamente posible de sus clérigos, de su lengua y de su cultura». Esa era la verdadera razón interna, no la explicación que se hacía pública, de su negativa a consentir la creación de escuelas españolas en Orán, donde, ciertamente, había 200.000 españoles por sólo 100.000 franceses $^{76}$. Esta política de asimilación rápida, por otra parte, era compartida por las distintas ramas de la administración, empezando por el cuerpo docente francés, protegido de la concurrencia extranjera por el estatuto de la función pública y por la prohibición a los extranjeros de dirigir establecimientos escolares - lo que de paso les hacía relativamente impermeables a las tendencias xenófobas. Y no sólo por la administración: había una especie de unanimidad que incluía las asociaciones patronales, los publicistas, y el conjunto de la opinión pública.

Asimilación cultural y naturalización jurídica eran dos fenómenos que marchaban unidos en el proceso de integración y «conquista» del emigrante. Y ello no sólo en el plano de las políticas y de las prácticas efectivamente aplicadas, sino también en el plano del discurso. De hecho, en el lenguaje ordinario, adquirir «la condición de nacional» significa mucho más que adquirir un status jurídico; tiene un componente sentimental y cultural innegable, y supone compartir una mentalidad, una forma de pensar y de sentir característica de una comunidad. La asimilación, frente a la exclusión, se convirtió en el signo distintivo de la actitud francesa hacia los inmigrantes. En realidad, con esta actitud se trataba de dar una solución al problema de cómo hacer compatibles dos principios antitéticos como son el de mantener una fuerte identidad nacional y el de integración de los extranjeros. Una solución que combinaba en un mismo proceso deculturación, impregnación cultural, asimilación e integración, y que llegó a convertirse en un dogma de la política francesa hacia la inmigración que sólo recientemente comienza a ser discutido. La teoría del «creuset» francés nos presenta la construcción de la nacionalidad francesa como un fabuloso esfuerzo de asimilación de sucesivas oleadas de población, que son integradas consecutivamente en el cuerpo nacional gracias a la gran capacidad de fusión de su sistema social. En ese proceso la escuela habría jugado un papel fundamental por la capacidad que tiene el sistema escolar de asimilar los jóvenes extranjeros a la nación francesa.

A menudo se han alabado las virtudes de este sistema de asimilación francés por comparación con el modelo multiculturalista anglosajón. Este último sí consentía una aceptación pluralista de los emigrantes, permitiéndoles preservar su propia cultura, pero a cambio de generar diferenciación y exclusión. La única alternativa a la asimilación del modelo francés parece ser la exclusión y la creación de ghetos sociales. Raramente, sin embargo, se pone de manifiesto la faceta oculta de este modelo de integración asimilacionista. Su principal incon-

76 Vid. Lorenzo DELGADO y Antonio NiÑo, «Emigración, enseñanza y nacionalidad ..., art. cit. 
veniente es seguramente el daño que ocasionaba a la personalidad y a la autoestima de los individuos que se veían sometidos a ese proceso. Las personas se conciben a sí mismas en el seno de una cultura, están apegadas a su propia cultura no sólo en el sentido de que poseen una lengua y unos recursos simbólicos, sino que, como dicen los antropólogos, son poseídos por ella, han sido construidas a partir de los significados y de las expresiones que se adquieren en la vida social. Los lazos con el país, la cultura y la familia de origen son elementos centrales de la personalidad. El mantenimiento de esos lazos con el país de origen se presenta bajo aspectos que pueden ser muy diferentes: lengua, tradiciones, hábitos alimenticios, costumbres y modos de vida, formas religiosas, etc. Evidentemente, todo ese conjunto evoluciona al entrar en contacto con la cultura francesa, y es posible que algunas personas, al presentárseles la posibilidad de elección, optaran por asimilarse a otra cultura impulsados por muy diversas razones. Al fin y al cabo, el derecho a la propia cultura debe combinarse con el derecho a elegir otros repertorios culturales. Pero cuando el cambio cultural es forzado, cuando la asimilación equivale a «deculturación», los efectos pueden ser traumáticos desde el punto de vista de la personalidad. En ese caso no hay asimilación "sin dolor». Romper con los lazos que unen al individuo con su comunidad de origen genera en muchas ocasiones inadaptados sociales, que no solamente no se integran en la sociedad adoptiva, sino que pueden llegar a convertirse en una amenaza para ella ${ }^{77}$.

La concepción de la nación francesa como una entidad estrechamente integrada, un «tejido sin costuras», hacía muy difícil una integración que preservara al mismo tiempo la diversidad. No había lugar para la diversidad cultural, que implica combinación, pluralidad y confluencia de tradiciones independientes. La posesión de las formas culturales oficiales era la única alternativa que otorgaba prestigio y reconocimiento social, mientras que la diferencia equivalía a la permanencia en posiciones sociales subordinadas. En esa tarea jugaban un papel muy eficaz los estereotipos negativos hacia la cultura extraña, estigmatizada continuamente como inferior, atrasada o bárbara. Estos estereotipos atacan la dignidad del individuo y le sitúan en una posición de inferioridad social respecto al resto de los ciudadanos. La «identidad nacional» es también una cuestión de dignidad personal y colectiva; proporciona a la gente razones para

77 La sociedad francesa ha conocido en las últimas décadas este fenómeno alarmente, protagonizado por jóvenes que habitan el extrarradio de las grandes ciudades, y agravado por la incomprensión del Islam, la crisis económica y la falta de perspectivas de ascenso social. Esto está llevando a una revisión del modelo francés de integración. El Haut Conseil à l'Intégration, por ejemplo, consideraba hace pocos años que la vida comunitaria y el asociacionismo en el grupo de origen son, sobre todo al principio, necesarias para la integración del individuo. La integración pasa ahora por el reconocimiento del otro, y no necesariamente por la desnacionalización cultural de la población inmigrante. Se ha llegado a la conclusión de que la indiferencia respecto a la herencia nacional o el pasado propio dificulta la integración de cualquier conjunto social, mientras que el orgullo de pertenecer a un colectivo nacional favorece la cohesión y la solidaridad social.

Hispania, LXII/2, núm. 211 (2002) 433-482 
sentirse orgulloso; forma parte del deseo de reconocimiento natural de cualquier grupo, y cuando ese reconocimiento no se produce, o se produce en forma de estereotipos negativos, se genera un sentimiento de dignidad herida y ultrajada. Por eso, para muchos emigrantes la naturalización equivalía a una renegación, a una pérdida traumática de sus señas de identidad. No sólo significaba la pérdida de la nacionalidad de origen, sino una escisión entre el status jurídico y el estatus personal y social.

Todo estos mecanismos eran reconocidos de algún modo por las autoridades consulares españolas y utilizados con el fin primordial de preservar la nacionalidad de los emigrados. «Para que sirvan a España - aconsejaba el cónsul en Cette- es necesario infundirles, fomentar y exaltar su patriotismo, sentimiento primordial que nadie se ocupó de cultivar ni antes ni después de su salida de la Patria. Lejos de ello, el emigrante español ha llevado siempre del otro lado de las fronteras un dogma de conciencia: el de su inferioridad» ${ }^{78}$. $\mathrm{Pa}$ rece que la débil nacionalización del ciudadano español, aún antes de su expatriación, era una dificultad más en la tarea de mantener los vínculos con su país de origen. El patriotismo, entendido como el legítimo orgullo de pertenecer a su nacionalidad de origen, podía ser el más eficaz antídoto contra la naturalización. Por eso recomienda el mismo cónsul actuar proporcionándole «lecciones de cosas, con poca abstracción, dedicadas a inteligencias poco despiertas, destinadas a lavarlas del prejuicio de la inferioridad y a exaltar el sentimiento innato que acaso no espera más que la voz amiga que le mande España».

Por otro lado, todos los testimonios de las autoridades españolas en contacto con la emigración reconocen la importancia de lo que se podrían llamar las estructuras de encuadramiento de la población inmigrante, los círculos de sociabilidad que representaban la voluntad de afirmar la nacionalidad de los emigrantes: asociaciones, clubs sociales o deportivos, mutualidades de socorro mutuo, etc. Todas estas iniciativas tenían el efecto de preservar la identidad de origen, permitiendo una integración social si traumas, pero haciendo más lento el proceso de asimilación en la sociedad francesa

No sólo el gobierno español, sino también otros gobiernos extranjeros con una masa importante de nacionales expatriados estaban empeñados en impedir o al menor ralentizar la desnacionalización de sus emigrados. El Gobierno italiano era el que hacía esfuerzos más denodados - sobre todo en ciertas regiones sensibles, como Saboya - intentando encuadrar a los emigrantes italianos en los fasci all'estero, y utilizando los convenios que le permitían atender a sus escolares en cursos especiales complementarios. El temor a que los Gobiernos extranjeros ejercieran un control político sobre sus colonias de nacionales acabó endureciendo aún más la posición del Estado francés. Para el Ministerio de Instrucción Pública francés se trataba de un problema de defensa nacional, y la

78 Despacho del Cónsul de Sête, 24 de enero de 1930, al Inspector General de Emigración, AGA, Trabajo, $75 / 23084$. 
única manera de evitar ese peligro era el rápido afrancesamiento de los inmigrantes. En consecuencia, la creación de escuelas extranjeras sólo podía ser un obstáculo a la política de rápida asimilación.

Por eso el verdadero conflicto no estuvo tanto en el asociacionismo como en el terreno escolar. La batalla que libraron las administraciones francesa y española por la escolarización de los hijos de los emigrantes fue larga, áspera y llena de maniobras obstaculizadoras. El contencioso se inauguró en 1921 con el intento de construir una escuela española en Bayona, y no se cerró hasta diez años después. Lo abrió un gobierno español monárquico y constitucional, lo prolongó un gobierno dictatorial, y lo cerró un Gobierno republicano ${ }^{79}$. En 1931 las nuevas autoridades republicanas acordaron, por pragmatismo, aceptar el ofrecimiento hecho por el gobierno francés de crear cursos de español en las escuelas públicas francesas, en lugar de autorizar escuelas propiamente españolas, con maestros nombrados y sostenidos por el gobierno español ${ }^{80}$. Se trataba de aceptar una derrota en aras del pragmatismo. Se renunciaba al principio de reciprocidad, y se daba por perdido el largo contencioso mantenido con el gobierno francés, pero la solución aceptada permitía poner en marcha inmediatamente un dispositivo de maestros destacados en las localidades de mayor concentración de emigrantes, que darían a los hijos de éstos clases de lengua, literatura, e historia españolas fuera de las horas regulares de clase

En contraste llamativo con la posición francesa de negativa intransigente a permitir que el Gobierno o las colectividades españolas crearan escuelas propias en su territorio, a las numerosas escuelas francesas en España se las trataba con una tolerancia extrema. Es más, un informe del encargado de la inspección de las escuelas francesas en España reconocía que ninguna de las escuelas francesas estaba en situación legal, sobre todo porque sus directores no tenían la nacionalidad española como exigía la ley. Su conclusión era algo cínica: en la práctica no había nada que temer porque en España faltaban escuelas, porque la calidad de las escuelas francesas era superior, y porque no habían dado motivo de queja a las autoridades ${ }^{81}$. El embajador hacía suya esta opinión y recomendaba a su Gobierno que no se rechazara de plano la autorización de crear escuelas españolas en Francia, Marruecos o Argelia, para dar satisfacción a la susceptibilidad española, pero mostraba su confianza en «que nuestras autoridades po-

$79 \mathrm{El}$ análisis detallado de este contencioso se encuentra en el artículo de Lorenzo DELGADo y Antonio NiÑO, «Emigración, enseñanza y nacionalidad ..., art. cit.

80 Vid. Nota del ministro francés de Negocios Extranjeros al embajador español en París de 4 de diciembre de 1929, acuerdo de la Sección de Relaciones Culturales de 26 de octubre de 1931, y nota del Ministerio francés de 17 de febrero de 1932 ratificando el acuerdo, AMAE, R-8586/22. El acuerdo para utilizar el mismo procedimiento en Argelia exigió otra negociación que demoró dos años más su puesta en práctica en la colonia, aunque el contencioso, en ese caso, databa de 1904.

81 «Note sur la situation légale des écoles françaises en Espagne», unida al despacho del embajador Peretti de la Rocca de 30 novembre 1925, AD, Europe, 1918-1929, Espagne, 122. Vid también J.-M. Delaunay, Des palais en Espagne, Madrid, Casa de Velázquez, 1994, p. 213, 
drán hacer uso de formalidades para que el asunto vaya para largo». Aunque el Gobierno español estudió la posibilidad de tomar represalias en contra de los establecimientos escolares franceses en España como medida de presión para lograr un trato equitativo, esta posibilidad nunca les pareció verosímil a los diplomáticos franceses. Y si el embajador destacado en Madrid recomendaba no atender a las peticiones españolas, aunque procurando no herir su orgullo, el Ministerio de Instrucción Pública francés rechazaba de plano la posibilidad de autorizar la apertura de escuelas reservadas a extranjeros porque podían fomentar, según sus responsables, la constitución de "minorías nacionales» dentro del país. El mismo Ministerio, sin embargo, había aceptado con normalidad un convenio relativo al intercambio de repetidores y lectores de español en las universidades y Escuelas Normales francesas ${ }^{82}$. Es obvio que en este caso la presencia de maestros españoles para enseñar su lengua se consideraba un refuerzo a la enseñanza de lenguas vivas en el sistema educativo francés, y no una amenaza al proceso de asimilación de los hijos de inmigrantes.

La solución del contencioso fue desfavorable para las pretensiones españolas, pero aún así fue posible sólo gracias a que las mismas facilidades con limitaciones se habían concedido ya a otros gobiernos. Ni siquiera permitió el Gobierno francés que el acuerdo tuviera el carácter de convenio oficial, y se mantuvo como un simple arreglo verbal. La puesta en marcha de esos cursos extraescolares no se hizo, además, sin fuertes resistencias de los directores de los establecimientos, de los inspectores de academia y del propio Ministerio de Instrucción Pública. La insistencia y determinación de los nuevos responsables republicanos españoles logró vencer numerosas trabas y retrasos, hasta conseguir que las clases comenzaran a impartirse desde diciembre de 1932, cuando ya muchas familias españolas comenzaban el retorno a su país por la crisis económica. A pesar de todas sus limitaciones, esta solución fue durante mucho tiempo una excepción en Europa, pues en el periodo de la emigración masiva de los años cincuenta y sesenta ningún otro Gobierno, excepto el británico, permitió que las clases de lengua, historia y geografía españolas fueran dispensadas en sus estructuras escolares.

Los seis maestros enviados ese primer año ejercieron en París, Toulouse, Bayona, Burdeos, Sète y Perpiñán. En los años siguientes fue aumentando lentamente el número de maestros destinados en el extranjero. Sólo en el departamento del Sena, donde se hizo un censo escolar en mayo de 1932, se contabilizaba un número de niños españoles en las escuelas primarias públicas de 2.726 escolares, repartidos en 60 escuelas, y contando únicamente aquéllas en las que había más de 20 niños de esa nacionalidad ${ }^{83}$. Había escuelas, como la

82 Vid. "Convenio relativo al intercambio de asistentes para los Institutos, Escuelas Normales, de Comercio e Industriales de España, y para los liceos, Colegios, Escuelas Normales primarias y primarias superiores de Francia», de 15 de mayo de 1913. Junta para Ampliación de Estudios, Memoria de los años 1912-13, pp. 192-196.

83 Cuadro anejo al despacho 922 de la embajada en París, AMAE, R.8586/22. 
que se inauguró en enero de 1932 en Aubervilliers, donde la mitad de los escolares, 250 niños, eran de nacionalidad española.

Estos cursos complementarios quedaron siempre al margen del sistema educativo francés, sin ningún tipo de relación con el resto de las clases, pero sometidos sin embargo a la autoridad del director francés del establecimiento. Aún así, la labor de los maestros enviados por la República española fue extraordinaria. Cada uno repartía su dedicación entre varios establecimientos escolares, y no sólo atendían las necesidades de la población infantil, sino que también se encargaron de impartir cursos para adultos, destinados a la población obrera, y de organizar conferencias de «educación cívica» entra la población emigrante. Para los emigrantes las clases de español eran importantes porque se entendían como una forma de facilitar el retorno: se trataba de que los hijos, o los mismos padres, no encontrasen dificultades de integración al regresar a España.

Algo parecido ocurrió con el Tratado de Trabajo y de Asistencia Social insistentemente solicitado por las asociaciones de emigrantes, por los cónsules y aún por los prefectos franceses para evitar diferencias escandalosas en la protección que recibían los trabajadores españoles respecto a los franceses y aún respecto a los italianos o belgas ${ }^{84}$. España era el único país con una importante población trabajadora en Francia que a comienzos de la década de los treinta aún no había firmado un acuerdo laboral. Los obreros españoles estaban protegidos por la ley de accidentes de trabajo pero su familia, de no residir en Francia al ocurrir el fallecimiento, no disfrutaba de derechos de indemnización alguno. Si eran víctimas de un accidente y obtenían una pensión, debían vivir en Francia si no querían perderla. No les eran aplicadas las disposiciones concernientes al paro forzoso, representación en los sindicatos, retiros obreros, asistencia a la maternidad, a la vejez y a la protección de la infancia. Tampoco tenían derecho a la hospitalización gratuita en caso de indigencia, lo que ocasionaba mil incidentes en los consulados, que no podían dejar abandonados a los enfermos en la calle, pero que tampoco podían abonar los gastos de hospitalización que les reclamaban las Prefecturas cuando se hospitalizaba a algún súbdito español.

La negociación del Tratado ya se había propuesto desde 1920, pero la poca diligencia de la diplomacia española hizo que el asunto se arrastrara una década sin alcanzar una solución. Fue de nuevo el Gabinete de Azaña el que alcanzó un acuerdo, aprovechando la visita de Herriot a Madrid el 2 de noviembre de 1932 para firmarlo. Aun así, las necesarias ratificaciones parlamentarias retrasaron su promulgación hasta el 16 de enero de 1934, y su entrada en vigor hasta el 1 de enero de 1935, es decir, cuando la emigración española a Francia estaba en pleno reflujo.

84 En 1919 se había firmado el primer Tratado de Trabajo entre Francia e Italia, modelo que inspiraría todos los demás: la Convención sobre asistencia y previsión social entre Francia y Polonia de 1920, la Convención sobre asistencia entre Bélgica y Francia de 1921 y el Tratado de Trabajo entre Bélgica y Francia de 1924.

Hispania, LXII/2, núm. 211 (2002) 433-482 


\section{DE LA ASIMILACIÓN A LA EXCLUSIÓN. El CAMBIO DE LA POLÍTICA FRANCESA HACIA LA INMIGRACIÓN}

La actitud francesa ante la inmigración fue cambiando rápidamente desde mediados de los años veinte. Se pasó de considerar la emigración una solución al declive demográfico, a considerarla un problema. El discurso oficial dejó de hablar de la necesidad de recibir un flujo constante de extranjeros para atender las necesidades del mercado laboral, y empezó a tratarlo como un peligro. En 1926 cundió en Francia el temor a la crisis económica. Se trataba en realidad de una crisis reducida a ciertas industrias y de efectos pasajeros, provocada por el alza del franco, pero estas dificultades se interpretaron enseguida como un problema de «exceso de mano de obra». Se extendió entonces la opinión de que había que discriminar a los trabajadores extranjeros mientras hubiera obreros franceses disponibles en el mismo ramo. Una ley de 11 de agosto de 1926 sobre "protección del mercado de trabajo nacional» condicionaba la contratación de un trabajador extranjero a la inexistencia de personal francés cualificado para ocupar el empleo deseado. Los despidos comenzaron entre los 35.000 obreros españoles que se aglomeraban en la región de París, especialmente entre los trabajadores especializados del sector metalúrgico, la ebanistería y el calzado, no así entre los peones. El propio secretario de la CGT francesa declaraba a un periodista español: "No queremos, desde luego, que sean expulsados estos honrados trabajadores so pretexto de la crisis (...) pero no debemos impedir su repatriación voluntaria con inconvenientes de consulado... Y además debe cortarse desde ahora su emigración, pues los que viniesen no encontrarían trabajo y agravarían la situación de los que viven ya entre nosotros» ${ }^{85}$.

La nueva política de la prioridad nacional en el mercado laboral se acompañó de una batería de medidas administrativas destinadas a impedir la llegada de nuevos inmigrantes. El 26 de febrero de 1927 el Gobierno francés dirigió dos circulares a todas las Misiones extranjeras en las que anunciaba que a partir de entonces todo extranjero que entrara en Francia para ocupar un empleo retribuido debía estar provisto de un certificado médico visado por el consulado francés y poseer un contrato de trabajo visado por el Servicio Central de la Mano de Obra del Ministerio de Trabajo o del Ministerio de Agricultura; en caso contrario, no podría obtener la tarjeta de identidad y se vería obligado a abandonar el territorio afrontando él mismo los gastos.

Un paso más en esa evolución se produjo cuando en la sociedad francesa empezó a generalizarse la opinión de que la inmigración no sólo era una concurrencia inaceptable para el trabajo nacional, sino también un grave riesgo para la identidad nacional. Un profesor de la Sorbonne, experto en estos temas, pedía en 1927 que se aplicara una política de inmigración inspirada "por conside-

85 «La situación económica de Francia y los obreros españoles», La Libertad, 25-XII-1926.

Hispania, LXII/2, núm. 211 (2002) 433-482 
raciones nacionales» ${ }^{86}$ - que no es lo mismo que nacionalistas o xenófobas, aclaraba el autor-. El objetivo principal, sostenía en su concienzudo análisis, debía ser su reducción, y eso se podría conseguir mediante una rigurosa selección de los inmigrantes basada en diversos criterios. Criterios físicos, en primer lugar: rechazar a los lisiados y enfermos contagiosos para evitar «la saturación de nuestros hospitales por los enfermos extranjeros». Criterios morales: rechazar a criminales y bolcheviques que son los causantes del gran número de crímenes cometidos por extranjeros. Criterios profesionales: sólo debían admitirse los extranjeros dispuestos a desempeñar profesiones que requieren fuerza física, como la de agricultor o minero, que son las primeras que abandonan los franceses. Criterios raciales también: aunque la nación francesa no constituía una raza, señalaba el profesor, «las razas que han constituido el pueblo francés eran todas blancas». El problema era que la llegada de amarillos y negros no podía ser considerada una inmigración extranjera puesto que eran súbditos coloniales, pero era una novedad de todo punto rechazable, opinaba el profesor, que se mostraba muy sensible a la necesidad de asegurar la prosperidad de las colonias y de garantizar el bienestar de sus indígenas: «traer negros o amarillos a Francia supone hacerlos diezmar por el clima, equivale a cometer un acto que condenan los principios de humanidad más elementales». Una vez asegurado que los inmigrantes eran asimilables por su raza, quedaba por último la selección por criterios nacionales. Nadie desearía, por ejemplo, una inmigración alemana. Entre los otros pueblos, eran preferibles «aquellos en los que el sentimiento nacional era menos fuerte: en este capítulo los españoles valen mejor que los italianos. Hay que preferir también aquellos cuyos gobiernos hacen menos esfuerzos para mantenerlos bajo su obediencia: desde este punto de vista también la inmigración italiana plantea dificultades particulares». Por último, había que prevenir cualquier riesgo impidiendo que los inmigrados formaran grupos compactos, «verdaderos islotes extranjeros en medio de Francia». También el profesor era partidario de alejarlos de las fronteras y diseminarlos por las zonas rurales. Había pues extranjeros deseables e indeseables, útiles e inútiles, asimilables y refractarios. Los españoles, según estas consideraciones inspiradas en «el punto de vista nacional», parecían en definitiva los que menos inconvenientes planteaban a la esperada asimilación.

A partir de los años treinta, una verdadera crisis económica golpeó a todos los sectores productivos y se agudizó la escasez de trabajo. El paro sacudió especialmente a los trabajadores inmigrantes, que acudían por miles a los consulados españoles solicitando un billete gratuito de repatriación, faltos de recursos para emprender el viaje de vuelta a su país. Los consulados lanzaban angustiosas llamadas al Ministerio de Estado pidiendo fondos para atender las repatriaciones de los más indigentes. Al mismo tiempo, aumentaban las difi-

86 Jean BOURDON, «L'immigration étrangère en France», Revue des Sciences Politiques, tome L (abril-junio 1927), pp. 273-283.

Hispania, LXII/2, núm. 211 (2002) 433-482 
cultades administrativas que se ponían a los extranjeros. Un decreto del Gobierno francés de 23 de octubre de 1933 exigía a todos los extranjeros una tarjeta de identidad y autorización de residencia. Para obtener estos documentos debían probar que habían entrado en Francia de modo regular y presentar a dos ciudadanos franceses como fiadores, y estaban obligados a visar su tarjeta de identidad cada vez que cambiaran de domicilio. Si pretendían ocupar un empleo asalariado debían, además, presentar un certificado sanitario y un contrato de trabajo visado por los servicios laborales del Ministerio de Agricultura o del Ministerio de Trabajo, y todo ello bajo pena de expulsión y aplicación del código penal en caso de incumplimiento.

El embajador español informaba indignado al Gobierno de la Segunda República de la actitud de las autoridades francesas: «La dura campaña emprendida contra la mano de obra extranjera continúa desarrollándose con intensidad creciente, llegando a extremos desprovistos no solo de toda equidad, sino también contrarios a todo principio moral» ${ }^{87}$. A los obreros se les retiraban sus documentos y se les entregaba una orden de expulsión perentoria con amenaza de prisión. Los obreros, desprovistos de jornal, acudían a los consulados para solicitar la repatriación, y éstos se quedaban pronto sin fondos. El embajador proponía no costear las repatriaciones, que vendrían a agravar el problema del paro en España, en la creencia de que las autoridades francesas no llegarían a encarcelar a los obreros porque resultaba más cara su manutención que los gastos de expulsión. El Ministerio español, por su parte, llegó a estudiar medidas de retorsión y represalia contra los ingenieros y empleados franceses en España, que naturalmente no se pusieron en práctica.

La tendencia en los años treinta fue la creciente politización del tema de la inmigración y su asociación a las cuestiones de identidad. Con el aumento de las tensiones sociales en el país, la noción del extranjero adquirió nuevas connotaciones de peligrosidad hasta acabar concentrando gran parte de los miedos y las angustias de la población francesa. Se pasó de hablar de «los indeseables entre los extranjeros, a los extranjeros indeseables», en una deriva que habría de convertir al extranjero en el chivo expiatorio de la creciente inseguridad nacional. En 1935 se creó el «Centre d'étude du problème des étrangers en France», presidido por Henri de Jouvenel y situado en la École Normale Supérieure, con el fin de «reunir toda la documentación precisa concerniente al problema de los extranjeros en Francia, y especialmente los resultados de encuestas objetivas y llevadas a cabo científicamente ${ }^{88}$, lo que era un indicio de que también en los medios intelectuales y académicos empezaba a calar la visión de la inmigración como un problema.

Esta evolución en la percepción del inmigrante tuvo consecuencias, como era previsible, en la estrategia de la asimilación seguida hasta entonces. El de-

87 Despacho del embajador en París, 22 de abril de 1935, AGA, Trabajo, 75/23093.

88 Vid. Olivier LOUBES, art. cit., p. 263. 
bate político en torno a la nacionalidad se impregnó de vehementes y apocalípticos argumentos. La creciente llegada de refugiados políticos -rusos, alemanes, españoles - hizo que se cuestionaran las facilidades de adquisición de la nacionalidad francesa por la vía de la naturalización. La política de asimilación en general era cada vez más contestada a medida que se extendía la xenofobia y el fantasma del peligro del inmigrante. Este ya no era apreciado por su aportación al esfuerzo económico del país, sino temido por miedo a una supuesta colonización de Francia. El gobierno Daladier, en la primavera de 1938, impuso decisiones reglamentarias muy estrictas respecto a los extranjeros ${ }^{89}$. Las tendencias xenófobas y el discurso de exclusión hacia los inmigrantes se extendieron más allá de la extrema derecha, ganaron a los sectores moderados y contaminaron a una parte de la izquierda ${ }^{90}$. En un país en crisis de identidad, sometido a fuertes tensiones internacionales y a crecientes enfrentamientos ideológicos, aumentaban las prevenciones hacia el extranjero. El extranjero pasó a ser un intruso más o menos peligroso, con connotaciones subversivas a medida que aumentaba el número de refugiados políticos. De ser un actor económico indispensable pasó a ser un elemento indeseable, inasimilable y desleal, que despertaba el temor a la formación de una quinta columna en el interior del país. La identidad nacional francesa se deslizaba rápidamente hacia una ideología «identitaria» basada en el origen y en la pertenencia, construida por oposición a lo foráneo. A partir de 1938, con el fin del Frente Popular, y sobre todo a partir de 1939, con la llegada de una masa importante de refugiados españoles, se mezclaron en el imaginario social francés el miedo al extranjero con el miedo a la guerra civil y social, lo que explica seguramente la forma en que fue recibido el exilio republicano. Finalmente el régimen de Pétain, entre 1940 y 1944, consumó la sustitución de la lógica de la asimilación por la de la exclusión.

89 Vid. los decretos-leyes de 2 de noviembre 1938 relativos a la naturalización de extranjeros.

90 Vid. LABORIE, Pierre, «Les espagnoles et les italiens dans l'imaginaire social», en MILZA, Pierre y PESCHANSKI, Denis (dirs.), Exils et migrations. op. cit. 